\title{
New Briarane Diterpenoids from Taiwanese Soft Coral Briareum violacea
}

\section{Chia-Ching Liaw ${ }^{1,2}$, Yuan-Bin Cheng ${ }^{1,3}$, Yun-Sheng Lin ${ }^{1,4}$, Yao-Haur Kuo ${ }^{5}$, Tsong-Long Hwang ${ }^{6}$ and Ya-Ching Shen ${ }^{1, *}$}

1 School of Pharmacy, College of Medicine, National Taiwan University, Taipei 100, Taiwan;

E-Mails: biogodas@hotmail.com (C.-C.L.); jmb@kmu.edu.tw (Y.-B.C.);

x00010106@meiho.edu.tw (Y.-S.L.)

2 Department of Marine Biotechnology and Resources, National Sun Yat-Sen University, Kaohsiung 804, Taiwan

3 Graduate Institute of Natural Products, School of Pharmacy, Kaohsiung Medical University, Kaohsiung 807, Taiwan

4 Department of Biological Science \& Technology, Mei Ho University, Pingtung 912, Taiwan

5 Division of Chinese Materia Medica Development, National Research Institute of Chinese Medicine, Taipei 112, Taiwan; E-Mail: kuoyh@nricm.edu.tw

6 Graduate Institute of Natural Products, Chang Gung University, Taoyuan 333, Taiwan; E-Mail: ht1@mail.cgu.edu.tw

* Author to whom correspondence should be addressed; E-Mail: ycshen@ntu.edu.tw; Tel.: +886-2-2312-3456 (ext. 62226); Fax: +886-2-2391-9098.

Received: 28 May 2014; in revised form: 24 July 2014 / Accepted: 24 July 2014 /

Published: 22 August 2014

\begin{abstract}
Ten new briarane diterpenoids, briaviolides A-J (1-10), together with six known briaranes, solenolides $\mathrm{A}$ and $\mathrm{D}$, excavatolide $\mathrm{A}$, briaexcavatolide $\mathrm{I}$,

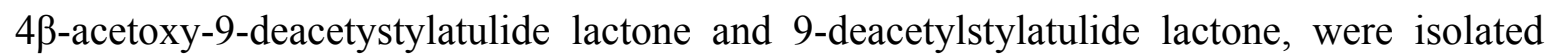
from the Taiwanese soft coral, Briareum violacea. Their structures were determined on the basis of spectroscopic data $\left({ }^{1} \mathrm{H}-\right.$ and ${ }^{13} \mathrm{C}-\mathrm{NMR},{ }^{1} \mathrm{H}-{ }^{1} \mathrm{H}$ COSY, HSQC, HMBC and NOESY), HR-MS and chemical methods. The absolute configuration of briaviolide A (1) was determined by X-ray crystallographic analysis. Compounds 5, 9 and derivative 11 showed moderate inhibitory activities on superoxide-anion generation and elastase release by human neutrophils in response to $N$-formyl-methionyl-leucyl-phenylalanine/ Cytochalasin B (fMLP/CB).
\end{abstract}


Keywords: Briareum violacea; briarane diterpenoids; briaviolides; anti-inflammatory activities

\section{Introduction}

The briarane diterpenoids [1] continue to attract the attention of natural product chemists because of their structural complexity and interesting biological activities, such as anti-inflammatory [2], antiviral [3], cytotoxic [4-6], antifouling [7,8], immuno-modulatory [9], insecticidal [10] and reversal of multidrug resistance [11]. The structures of these diterpenoids are characterized by a highly oxygenated bicyclo[8.4.0]tetradecane skeleton that is frequently attached with a $\gamma$-lactone moiety. Since the first structural elucidation of briarein A isolated from Briareum asbestinum in 1977 [12], more than 450 briarane-type diterpenoids have been reported from Octocorallia, including Gorgonacea, Pennatulacea, Alcyonacea and Stolonifera [13-15]. In serial studies of the Taiwanese gorgonian corals, many new briaranes have been isolated, including juncenolides A-G from Junceella juncea [16-18], frajunolides A-K from J. fragilis [19,20] and briaviodiol A from B. violacea [21].

In this paper, we report the investigation of Taiwanese soft coral Briareum violacea that provided ten new briarane-type diterpenoids, briaviolides A-J (1-10) (Figure 1), along with six known analogues, solenolides $\mathrm{A}$ and $\mathrm{D}$, excavatolide A, briaexcavatolide I, 4 $\beta$-acetoxy-9-deacetystylatulide lactone and 9-deacetylstylatulide lactone. The structures of new compounds were established by spectroscopic and chemical methods. Among them, the structure of $\mathbf{1}$ was further confirmed by single-crystal X-ray analysis. The in vitro anti-inflammatory activities of new compounds (1-10) and new derivative $\mathbf{1 1}$ were also tested for their inhibition of elastase release and superoxide-anion generation from human neutrophils.

Figure 1. Briaviolides A-J (1-10) isolated from Briareum violacea.

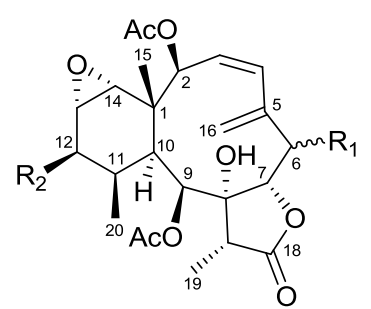

$1 \quad \mathrm{R}_{1}=\alpha-\mathrm{Cl}, \mathrm{R}_{2}=\mathrm{OH}$

$2 \mathrm{R}_{1}=\alpha-\mathrm{Cl}, \mathrm{R}_{2}=\mathrm{OCOCH}_{2} \mathrm{CH}_{3}$

$3 \mathrm{R}_{1}=\beta-\mathrm{OAc}, \mathrm{R}_{2}=\mathrm{OAC}$

$11 \mathrm{R}_{1}=\alpha-\mathrm{Cl}, \mathrm{R}_{2}=\mathrm{OBz}$

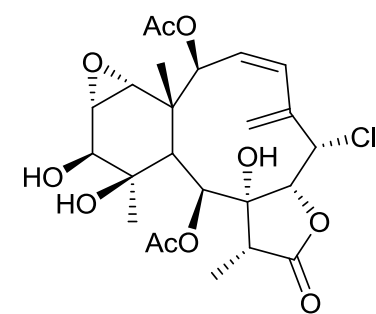

4

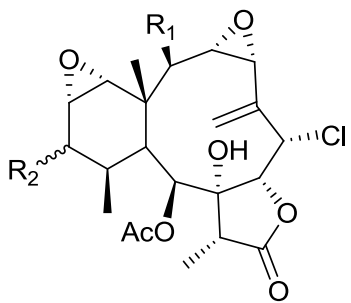

$5 \mathrm{R}_{1}=\mathrm{OAc}, \mathrm{R}_{2}=\beta-\mathrm{OCOCH} \mathrm{CH}_{2} \mathrm{CH}\left(\mathrm{CH}_{3}\right)_{2}$

$6 \mathrm{R}_{1}=\mathrm{OH}, \mathrm{R}_{2}=\alpha-\mathrm{OCO}\left(\mathrm{CH}_{2}\right)_{4} \mathrm{CH}_{3}$

$7 R_{1}=O A c, R_{2}=\alpha-O A c$

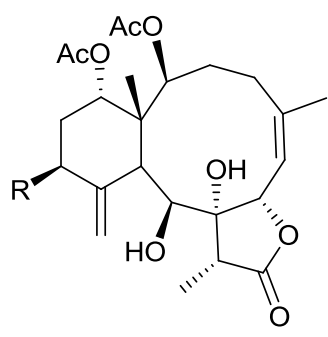

$8 \mathrm{R}=\mathrm{OH}$

$9 \mathrm{R}=\mathrm{OOH}$

$10 \mathrm{R}=\mathrm{OAC}$

\section{Results and Discussion}

Briaviolide A (1) was isolated as colorless prisms. Its ESIMS revealed two isotopic $[\mathrm{M}+\mathrm{Na}]^{+}$and $[\mathrm{M}+\mathrm{Na}+2]^{+}$peaks for pseudo-molecular ions at $\mathrm{m} / z 521$ and 523 (3:1) and HRESIMS at $m / z 521.1554[\mathrm{M}+\mathrm{Na}]^{+}$, indicating a molecular formula $\mathrm{C}_{24} \mathrm{H}_{31} \mathrm{O}_{9} \mathrm{Cl}$, which contains one chlorine atom and accounts for nine degrees of unsaturation. The IR spectrum of $\mathbf{1}$ showed absorption frequencies at 3524,1767 and $1737 \mathrm{~cm}^{-1}$, indicating the presence of hydroxyl, $\gamma$-lactone and carbonyl 
ester functionalities, respectively. The ${ }^{1} \mathrm{H}$ - and ${ }^{13} \mathrm{C}-\mathrm{NMR}$ spectroscopic data (Tables 1 and 2) exhibited signals of two acetate methyl singlets at $\delta_{\mathrm{H}} 2.09\left(\delta_{\mathrm{C}} 21.1\right)$ and $2.17\left(\delta_{\mathrm{C}} 22.1\right)$, with corresponding carbonyl signals at $\delta_{\mathrm{C}} 170.3,170.2$, respectively. The carbonyls showed respective HMBC connectivity (Figure 2) with two methine doublets at $\delta_{\mathrm{H}} 6.09$ and 5.30, revealing the positions of each acetate group (C-2 and C-9, respectively). The carbonyl signal of a $\gamma$-lactone $\left(\delta_{\mathrm{C}} 174.9\right)$ was connected with a secondary methyl doublet at $\delta_{\mathrm{H}} 1.17\left(\delta_{\mathrm{C}} 6.3\right)$ by the HMBC $(\mathrm{H}-19 / \mathrm{C}-18)$ and COSY $(\mathrm{H}-19 / \mathrm{H}-17)$ correlations. The connection between $\mathrm{C}-17$ and $\mathrm{C}-8\left(\delta_{\mathrm{C}} 83.9\right)$ was elucidated by the HMBC correlation from $\mathrm{H}-19$ to $\mathrm{C}-8$. The hydroxyl proton $\left(\delta_{\mathrm{H}} 3.52\right)$ of $\mathrm{C}-8$ was correlated with the adjacent lactonide carbon $\mathrm{C}-7$ and $\mathrm{C}-9$ by virtue of the $\mathrm{HMBC}$ correlations from $8-\mathrm{OH}$ to $\mathrm{C}-7$ and $\mathrm{C}-9$. These correlations along with the H-6/H-7 (COSY) correlation fixed the position of the lactone ring. The signals of an exocyclic double bond were observed at $\delta_{\mathrm{H}} 6.24(\mathrm{br} \mathrm{s})$ and $5.95(\mathrm{~d}, J=2.1 \mathrm{~Hz})\left(\delta_{\mathrm{C}} 118.7\right)$ and were conjugated with an endocyclic double bond at $\delta_{\mathrm{H}} 5.63\left(\mathrm{dd}, J=11.4,9.0 \mathrm{~Hz} ; \delta_{\mathrm{C}} 131.0\right), 5.90$ (d, $J=11.4 \mathrm{~Hz} ; \delta_{\mathrm{C}} 128.0$ ) by related HMBC and COSY correlations. The correlations of $\mathrm{H}-6 / \mathrm{H}-7$ (COSY) and $\mathrm{H}-16 / \mathrm{C}-6$ (HMBC) thus connected the conjugated double bond with the $\gamma$-lactone ring. The signals of a pair of methine protons at $\delta_{\mathrm{H}} 3.23(\mathrm{H}-13)$ and $\delta_{\mathrm{H}} 2.99(\mathrm{H}-14)$ were assigned for an epoxide ring. This moiety was neighbored on a quaternary carbon $\left(\delta_{\mathrm{C}} 40.6\right)$ and a hydroxylated carbon $\left(\delta_{\mathrm{C}} 70.5\right.$; $\left.\delta_{\mathrm{H}} 3.71\right)$ by the HMBC correlation of $\mathrm{H}-12 / \mathrm{C}-13$ and $\mathrm{H}-14 / \mathrm{C}-1$. The COSY correlations of $\mathrm{H}-12 / \mathrm{H}-11 / \mathrm{H}-20$ and $\mathrm{H}-9 / \mathrm{H}-10$ indicated the presence of two proton sequences. These two sequences were connected by the HMBC correlations of H-20/C-10 and H-9/C-11. By deducing the unsaturation of two acetates, conjugated diene, a $\gamma$-lactone ring and the epoxide ring, the remaining two degrees of unsaturation strongly suggested that Compound 1 possesses two additional rings belong to briarane-type diterpenoids.

A literature survey revealed that the ${ }^{1} \mathrm{H}$ - and ${ }^{13} \mathrm{C}-\mathrm{NMR}$ spectroscopic data of $\mathbf{1}$ showed similarity with those of briaexcavatolide I [22]. The only difference between them was $\mathbf{1}$ having two acetyl groups, while there are three in briaexcavatolide I. Acetylation of $\mathbf{1}$ gave a triacetyl product that was identical to briaexcavatolide I after comparing with their ${ }^{1} \mathrm{H}$ and ${ }^{13} \mathrm{C}$ NMR data. Benzoylation of 1 yielded a monobenzoyl derivative $\mathbf{1 1}$ that confirmed the secondary hydroxyl group at C-12.

The relative configuration of $\mathbf{1}$ was determined by NOESY (Figure 3a) and X-ray diffraction analysis (Figure 3b). Naturally occurring briaranes have $\beta$-face of Me-15 and $\alpha$-orientation of H-10. The NOESY correlations between H-2/H-16, H-2/H-10, H-10/H-12, H-12/H-11, H-11/H-9 and $\mathrm{H}-9 / \mathrm{Me}-19$ required that all of these groups were in $\alpha$-face, and correlations of $\mathrm{H}-6 / \mathrm{H}-7, \mathrm{H}-7 / \mathrm{H}-17$, Me-15/H-14 and H-14/H-13 indicated $\beta$-disposition for these groups. The correlations between $\mathrm{H}-16 / \mathrm{H}-2$ and $\mathrm{H}-2 / \mathrm{H}-10$ suggested that the conjugated diene had a s-cis geometry and forced the ten-membered ring to adopt a boat-like conformation with $\mathrm{C}-1$ and $\mathrm{C}-5$ at the bow and stern positions. An X-ray crystallographic analysis established the complete structure and stereochemistry of $\mathbf{1}$ as shown by the Oak Ridge Thermal Ellipsoid Plot (ORTEP) diagram stereo-drawing in Figure 3b. The negative optical rotation value of $\mathbf{1}$ was similar to that of briaexcavatolide I [23] in direction and magnitude, suggesting that $\mathbf{1}$ and briaexcavatolide I had $1 S, 10 S$-configurations in the ring junction. Thus, the structure of briaviolide A (1) was determined as $(1 S, 2 S, 3 Z, 6 S, 7 R, 8 R, 9 S, 10 S, 11 R, 12 R, 13 S, 14 R$, $17 R$ )-6-chloro-13,14-epoxy-2,9-diacetoxy-8,12-dihydroxybriaran-3(4),5(16)-dien-18,7-olide. 
Table 1. ${ }^{1} \mathrm{H}-\mathrm{NMR}$ spectroscopic data (in ppm, $J$ in Hz) of briaviolides A-J (1-10) and Compound 11.

\begin{tabular}{|c|c|c|c|c|c|c|c|c|c|c|c|}
\hline No. & 1 & 2 & 3 & 4 & 5 & 6 & 7 & $8^{\mathrm{a}}$ & $9^{b}$ & $10^{\mathrm{c}}$ & 11 \\
\hline 2 & $6.09(\mathrm{~d}, 9.0)$ & $6.12(\mathrm{~d}, 9.2)$ & $6.10(\mathrm{~d}, 9.5)$ & $6.21(\mathrm{~d}, 10.0)$ & $5.13(\mathrm{~d}, 9.3)$ & $3.66(\mathrm{~d}, 8.0)$ & $5.23(\mathrm{~d}, 9.5)$ & $5.34(\mathrm{~d}, 9.2)$ & $5.16(\mathrm{~d}, 7.6)$ & $5.76(\mathrm{~d}, 8.8)$ & $6.19(\mathrm{~d}, 9.0)$ \\
\hline \multirow[t]{2}{*}{3} & $5.63(\mathrm{dd}, 11.4,9.0)$ & $5.16(\mathrm{dd}, 11.2,9.2)$ & $5.61(\mathrm{dd}, 11.5,9.5)$ & $5.60(\mathrm{dd}, 11.6,9.6)$ & $3.39(\mathrm{dd}, 9.3,3.9)$ & $3.39(\mathrm{dd}, 8.0,3.6)$ & $3.41(\mathrm{dd}, 9.5,4.4)$ & $2.90(\mathrm{~m})$ & $2.90(\mathrm{td}, 14.8,5.2)$ & $3.32(\mathrm{~m})$ & $5.65(\mathrm{dd}, 12.0,9.0)$ \\
\hline & & & & & & & & $1.45(\mathrm{~m})$ & $1.49(\mathrm{~m})$ & $1.67(\mathrm{~m})$ & \\
\hline \multirow[t]{2}{*}{4} & $5.90(\mathrm{~d}, 11.4)$ & $5.89(\mathrm{~d}, 11.2)$ & $6.15(\mathrm{~d}, 11.5)$ & $5.93(\mathrm{~d}, 10.0)$ & $3.60(\mathrm{~d}, 4.0)$ & $3.72(\mathrm{~d}, 3.6)$ & $3.66(\mathrm{~d}, 4.0)$ & 2.47 (br d, 10.0) & $2.48(\mathrm{br} \mathrm{d}, 14.0)$ & $2.53(\mathrm{br} \mathrm{d}, 15.6)$ & $5.93(\mathrm{~d}, 12.0)$ \\
\hline & & & & & & & & $1.73(\mathrm{td}, 15.2,4.4)$ & $1.83(\mathrm{dd}, 14.0,4.4)$ & $1.80(\mathrm{~m})$ & \\
\hline 6 & $5.21(\mathrm{br} \mathrm{s})$ & $5.20(\mathrm{br} \mathrm{s})$ & $5.75(\mathrm{~d}, 10.0)$ & $5.08(\mathrm{br} \mathrm{d}, 2.8)$ & $5.37(\mathrm{~d}, 2.0)$ & $5.40(\mathrm{br} \mathrm{s})$ & $5.43(\mathrm{~d}, 3.5)$ & $5.31(\mathrm{~d}, 11.6)$ & 5.41 (br d, 9.6) & $5.88(\mathrm{~d}, 8.8)$ & $5.23(\mathrm{br} \mathrm{s})$ \\
\hline 7 & $4.94(\mathrm{~d}, 3.6)$ & $4.93(\mathrm{~d}, 3.2)$ & $4.66(\mathrm{~d}, 10.0)$ & $4.97(\mathrm{~d}, 4.4)$ & $5.03(\mathrm{~d}, 2.0)$ & 4.68 (br s) & $5.02(\mathrm{~d}, 3.0)$ & $5.52(\mathrm{~d}, 9.6)$ & $5.51(\mathrm{~d}, 10.0)$ & $6.01(\mathrm{~d}, 9.6)$ & $4.79(\mathrm{~d}, 3.6)$ \\
\hline 9 & $5.30(\mathrm{~d}, 7.8)$ & $5.24(\mathrm{~d}, 7.6)$ & $5.29(\mathrm{~d}, 8.0)$ & $5.76(\mathrm{~d}, 6.0)$ & $5.32(\mathrm{~m})$ & $5.30(\mathrm{~d}, 9.0)$ & $5.33(\mathrm{~d}, 9.0)$ & 4.68 (br s) & $4.40(\mathrm{~m})$ & $5.10(\mathrm{~m})$ & $5.30(\mathrm{~d}, 7.5)$ \\
\hline 10 & $1.95(\mathrm{dd}, 7.8,2.0)$ & $2.01(\mathrm{dd}, 7.2,2.0)$ & $2.03(\mathrm{~m})$ & $2.22(\mathrm{~d}, 6.0)$ & $1.74(\mathrm{dd}, 8.8,2.4)$ & $1.83(\mathrm{~m})$ & $2.04(\mathrm{dd}, 9.0,2.5)$ & $3.24(\mathrm{~s})$ & 3.18 (br s) & $3.89(\mathrm{~s})$ & $1.84(\mathrm{~d}, 7.2)$ \\
\hline 11 & $2.07(\mathrm{~m})$ & $2.05(\mathrm{~m})$ & $2.22(\mathrm{~m})$ & & $2.30(\mathrm{~m})$ & $2.30(\mathrm{~m})$ & $2.35(\mathrm{~m})$ & & & & $2.10(\mathrm{~m})$ \\
\hline 12 & $3.71(\mathrm{~d}, 4.2)$ & $4.62(\mathrm{~d}, 4.4)$ & $4.63(\mathrm{~d}, 5.0)$ & $3.56(\mathrm{~s})$ & $4.64(\mathrm{~d}, 4.8)$ & 4.68 (br s) & $4.70(\mathrm{dd}, 5.0,2.5)$ & $4.13(\mathrm{dd}, 10.8,5.2)$ & $4.40(\mathrm{~m})$ & $5.50(\mathrm{~m})$ & $4.99(\mathrm{~d}, 4.5)$ \\
\hline \multirow[t]{2}{*}{13} & $3.23(\mathrm{~d}, 3.3)$ & $3.15(\mathrm{~d}, 3.2)$ & 3.18 (br d, 1.5) & $3.24(\mathrm{~d}, 4.0)$ & $3.12(\mathrm{br} \mathrm{s})$ & $3.60(\mathrm{~m})$ & $3.53(\mathrm{dd}, 3.5,5.5)$ & $2.01(\mathrm{~m})$ & $2.09(\mathrm{ddd}, 14.4,6.0,3.2)$ & $2.38(\mathrm{~m})$ & $3.32(\mathrm{~d}, 3.0)$ \\
\hline & & & & & & & & $1.50(\mathrm{~m})$ & 1.67 (ddd, $14.4,9.2,3.2)$ & $1.86(\mathrm{~m})$ & \\
\hline 14 & $2.99(\mathrm{~d}, 3.6)$ & $2.97(\mathrm{~d}, 3.6)$ & $2.99(\mathrm{~d}, 3.0)$ & $2.94(\mathrm{~d}, 4.0)$ & $2.90(\mathrm{~d}, 3.6)$ & $3.24(\mathrm{~d}, 3.0)$ & $2.87(\mathrm{~d}, 3.0)$ & 4.68 (br s) & $4.73(\mathrm{t}, 3.2)$ & $5.10(\mathrm{~m})$ & $3.04(\mathrm{~d} 3.3)$ \\
\hline 15 & $1.13(\mathrm{~s})$ & $1.12(\mathrm{~s})$ & $1.14(\mathrm{~s})$ & $1.21(\mathrm{~s})$ & $1.23(\mathrm{~s})$ & $1.11(\mathrm{~s})$ & $1.19(\mathrm{~s})$ & $1.08(\mathrm{~s})$ & $1.17(\mathrm{~s})$ & $1.42(\mathrm{~s})$ & $1.17(\mathrm{~s})$ \\
\hline \multirow[t]{2}{*}{16} & 6.24 (br s) & $6.26(\mathrm{br} \mathrm{s})$ & $6.10(\mathrm{~s})$ & $6.23(\mathrm{br} \mathrm{s})$ & $6.13(\mathrm{~d}, 2.0)$ & $5.61(\mathrm{br} \mathrm{s})$ & $6.11(\mathrm{~d}, 2.5)$ & $1.85(\mathrm{~s})$ & $1.91(\mathrm{~s})$ & $2.04(\mathrm{~s})$ & $6.31(\mathrm{br} \mathrm{s})$ \\
\hline & $5.95(\mathrm{~d}, 2.1)$ & $6.00(\mathrm{~s})$ & $5.72(\mathrm{~s})$ & $5.94(\mathrm{~s})$ & $6.04(\mathrm{~d}, 2.0)$ & $5.98(\mathrm{~d}, 1.8)$ & $6.07(\mathrm{~d}, 2.5)$ & & & & $6.04(\mathrm{~d}, 1.8)$ \\
\hline 17 & $2.37(\mathrm{q}, 6.9)$ & $2.35(\mathrm{q}, 7.6)$ & $2.48(\mathrm{q}, 7.0)$ & $2.37(\mathrm{q}, 7.6)$ & $2.45(\mathrm{q}, 6.9)$ & $2.43(\mathrm{q}, 7.2)$ & $2.41(\mathrm{q}, 7.0)$ & $3.05(\mathrm{q}, 7.2)$ & $3.09(\mathrm{q}, 7.2)$ & $3.63(\mathrm{q}, 7.6)$ & $2.34(\mathrm{q}, 7.5)$ \\
\hline 19 & $1.17(\mathrm{~d}, 6.9)$ & $1.14(\mathrm{~d}, 7.6)$ & $1.16(\mathrm{~d}, 7.0)$ & $1.18(\mathrm{~d}, 7.6)$ & $1.18(\mathrm{~d}, 6.9)$ & $1.16(\mathrm{~d}, 7.2)$ & $1.19(\mathrm{~d}, 6.5)$ & $1.02(\mathrm{~d}, 7.2)$ & $1.06(\mathrm{~d}, 7.2)$ & $1.43(\mathrm{~d}, 7.6)$ & $1.18(\mathrm{~d}, 7.5)$ \\
\hline \multirow[t]{2}{*}{20} & $1.04(\mathrm{~d}, 6.9)$ & $1.05(\mathrm{~d}, 6.8)$ & $1.05(\mathrm{~d}, 7.0)$ & $1.29(\mathrm{~s})$ & $1.03(\mathrm{~d}, 6.9)$ & $1.05(\mathrm{~d}, 7.2)$ & $1.06(\mathrm{~d}, 7.5)$ & $5.45(\mathrm{~s})$ & $5.32(\mathrm{br} \mathrm{s})$ & $5.65(\mathrm{~s})$ & $1.16(\mathrm{~d}, 7.2)$ \\
\hline & & & & & & & & $5.22(\mathrm{~s})$ & 5.25 (br s) & $5.48(\mathrm{~s})$ & \\
\hline $2^{\prime}$ & & $2.38(\mathrm{~m})$ & & & $2.20(\mathrm{~m})$ & $2.28(\mathrm{~m})$ & & & & & \\
\hline $3^{\prime}$ & & $1.15(\mathrm{t}, 8.0)$ & & & $2.10(\mathrm{~m})$ & $1.61(\mathrm{~m})$ & & & & & $7.46(\mathrm{~m})$ \\
\hline $4^{\prime}$ & & & & & $0.96(\mathrm{~d}, 6.3)$ & $1.31(\mathrm{~m})$ & & & & & $7.59(\mathrm{t}, 7.2)$ \\
\hline $5^{\prime}$ & & & & & $0.96(\mathrm{~d}, 6.3)$ & $1.31(\mathrm{~m})$ & & & & & 7.47 (m) \\
\hline $6^{\prime}$ & & & & & & $0.90(\mathrm{t}, 7.0)$ & & & & & $7.59(\mathrm{t}, 7.2)$ \\
\hline $7^{\prime}$ & & & & & & & & & & & $7.46(\mathrm{~m})$ \\
\hline 2-OAc & $2.09(\mathrm{~s})$ & $2.07(\mathrm{~s})$ & $2.08(\mathrm{~s})$ & $2.18(\mathrm{~s})$ & $2.12(\mathrm{~s})$ & $2.20(\mathrm{~s})$ & $2.14(\mathrm{~s})$ & $1.90(\mathrm{~s})$ & $1.96(\mathrm{~s})$ & $2.06(\mathrm{~s})$ & $2.09(\mathrm{~s})$ \\
\hline 6-OAc & & & $2.07(\mathrm{~s})$ & & & & & & & & \\
\hline 9-OAc & $2.17(\mathrm{~s})$ & $2.15(\mathrm{~s})$ & $2.13(\mathrm{~s})$ & $2.08(\mathrm{~s})$ & $2.19(\mathrm{~s})$ & $2.20(\mathrm{~s})$ & $2.22(\mathrm{~s})$ & & & & $2.19(\mathrm{~s})$ \\
\hline $12-\mathrm{OAc}$ & & & $2.19(\mathrm{~s})$ & & & & $2.06(\mathrm{~s})$ & & & $2.05(\mathrm{~s})$ & \\
\hline $14-\mathrm{OAc}$ & & & & & & & & $1.90(\mathrm{~s})$ & $1.94(\mathrm{~s})$ & $1.85(\mathrm{~s})$ & \\
\hline 8-OH & $3.52(\mathrm{~s})$ & & $3.48(\mathrm{~s})$ & & & & & & & $7.38(\mathrm{~s})$ & $3.49(\mathrm{~s})$ \\
\hline $9-\mathrm{OH}$ & & & & & & & & & & $7.79(\mathrm{~d}, 7.6)$ & \\
\hline
\end{tabular}

${ }^{\mathrm{a}}$ Recorded in $d_{6}$-acetone at $400 \mathrm{MHz} ;{ }^{\mathrm{b}}$ Recorded in pyridine- $d_{5}$ at $400 \mathrm{MHz} ;{ }^{\mathrm{c}}$ Recorded in $\mathrm{CD}_{3} \mathrm{OD}$ at $400 \mathrm{MHz}$. 
Table 2. ${ }^{13} \mathrm{C}-\mathrm{NMR}$ spectroscopic data ( $\delta$ in ppm, mult.) of briaviolides A-J $(\mathbf{1}-\mathbf{1 0})$ and Compound $11^{\text {a }}$.

\begin{tabular}{|c|c|c|c|c|c|c|c|c|c|c|c|}
\hline No. & 1 & 2 & 3 & 4 & 5 & 6 & 7 & $8^{b}$ & $9^{c}$ & $10^{d}$ & 11 \\
\hline 1 & $40.6(\mathrm{~s})$ & $41.9(\mathrm{~s})$ & $40.8(\mathrm{~s})$ & $42.9(\mathrm{~s})$ & $38.3(\mathrm{~s})$ & $38.8(\mathrm{~s})$ & $38.5(\mathrm{~s})$ & $49.5(\mathrm{~s})$ & $48.9(\mathrm{~s})$ & $47.7(\mathrm{~s})$ & $41.9(\mathrm{~s})$ \\
\hline 2 & $75.5(\mathrm{~d})$ & 75.8 (d) & $75.3(\mathrm{~d})$ & $75.6(\mathrm{~d})$ & 74.9 (d) & 74.0 (d) & $75.5(\mathrm{~d})$ & $74.8(\mathrm{~d})$ & $76.6(d)$ & 73.4 (d) & $76.0(\mathrm{~d})$ \\
\hline 3 & $131.0(\mathrm{~d})$ & $130.4(\mathrm{~d})$ & $130.4(d)$ & $129.1(\mathrm{~d})$ & $60.0(\mathrm{~d})$ & $62.3(d)$ & 59.9 (d) & $32.3(\mathrm{t})$ & $32.4(\mathrm{t})$ & $30.1(\mathrm{t})$ & $130.6(\mathrm{~d})$ \\
\hline 4 & $128.0(\mathrm{~d})$ & $127.7(d)$ & 128.0 (d) & 129.1 (d) & $57.0(\mathrm{~d})$ & $57.8(\mathrm{~d})$ & $56.9(\mathrm{~d})$ & $29.5(\mathrm{t})$ & $29.4(\mathrm{t})$ & $27.3(\mathrm{t})$ & 127.9 (d) \\
\hline 5 & $136.6(\mathrm{~s})$ & $135.8(\mathrm{~s})$ & $137.2(\mathrm{~s})$ & $136.3(\mathrm{~s})$ & $133.3(\mathrm{~s})$ & $135.1(\mathrm{~s})$ & $133.9(\mathrm{~s})$ & $141.3(\mathrm{~s})$ & $144.0(\mathrm{~s})$ & $141.0(\mathrm{~s})$ & $135.8(\mathrm{~s})$ \\
\hline 6 & $62.4(\mathrm{~d})$ & $63.2(\mathrm{~d})$ & 75.3 (d) & $61.6(\mathrm{~d})$ & $61.1(\mathrm{~d})$ & $61.2(\mathrm{~d})$ & $61.1(\mathrm{~d})$ & 120.4 (d) & 121.7 (d) & $120.3(d)$ & $62.9(\mathrm{~d})$ \\
\hline 7 & $78.3(d)$ & 78.3 (d) & 81.5 (d) & 78.9 (d) & 76.4 (d) & 76.5 (d) & $76.2(d)$ & 79.9 (d) & 81.3 (d) & 79.4 (d) & 78.4 (d) \\
\hline 8 & $83.9(\mathrm{~s})$ & $84.4(\mathrm{~s})$ & $80.4(\mathrm{~s})$ & $82.5(\mathrm{~s})$ & 83.9 (s) & $84.9(\mathrm{~s})$ & $84.8(\mathrm{~s})$ & $83.6(\mathrm{~s})$ & $85.1(\mathrm{~s})$ & 82.9 (s) & $84.4(\mathrm{~s})$ \\
\hline 9 & $69.9(\mathrm{~d})$ & 70.5 (d) & 69.9 (d) & $68.6(\mathrm{~d})$ & $69.4(\mathrm{~d})$ & $68.7(\mathrm{~d})$ & $68.6(\mathrm{~d})$ & 75.7 (d) & $75.0(\mathrm{~d})$ & 73.9 (d) & $70.6(\mathrm{~d})$ \\
\hline 10 & $38.1(\mathrm{~d})$ & 38.9 (d) & $37.2(\mathrm{~d})$ & 41.5 (d) & $37.4(\mathrm{~d})$ & $32.9(\mathrm{~d})$ & $33.0(\mathrm{~d})$ & $41.8(\mathrm{~d})$ & $42.2(\mathrm{~d})$ & 40.5 (d) & 38.9 (d) \\
\hline 11 & $40.1(\mathrm{~d})$ & 39.1 (d) & $36.6(d)$ & 77.0 (d) & $36.0(\mathrm{~d})$ & 35.9 (d) & $35.9(\mathrm{~d})$ & $156.2(\mathrm{~s})$ & $152.1(\mathrm{~s})$ & $151.1(\mathrm{~s})$ & $38.6(\mathrm{~d})$ \\
\hline 12 & $70.5(d)$ & 73.7 (d) & 72.4 (d) & 74.9 (d) & $71.4(\mathrm{~d})$ & 69.7 (d) & $69.2(\mathrm{~d})$ & $69.4(\mathrm{~d})$ & 83.8 (d) & 70.5 (d) & $73.3(\mathrm{~d})$ \\
\hline 13 & $59.6(d)$ & 58.3 (d) & 57.1 (d) & 59.5 (d) & $56.7(d)$ & $53.0(\mathrm{~d})$ & $52.2(\mathrm{~d})$ & $38.7(\mathrm{t})$ & $33.8(\mathrm{t})$ & $33.4(\mathrm{t})$ & $58.3(\mathrm{~d})$ \\
\hline 14 & $62.9(\mathrm{~d})$ & $62.9(\mathrm{~d})$ & $62.0(\mathrm{~d})$ & $62.1(\mathrm{~d})$ & $61.4(\mathrm{~d})$ & $62.4(\mathrm{~d})$ & $61.3(\mathrm{~d})$ & 75.7 (d) & $76.3(\mathrm{~d})$ & $73.8(\mathrm{~d})$ & $63.2(\mathrm{~d})$ \\
\hline 15 & $16.0(q)$ & $17.7(q)$ & $15.6(q)$ & $15.5(q)$ & $16.4(q)$ & $15.7(q)$ & $16.4(q)$ & $15.2(q)$ & $14.9(q)$ & $12.9(q)$ & $17.6(q)$ \\
\hline 16 & 118.7 (d) & 119.1 (d) & $123.1(d)$ & $117.6(d)$ & $121.0(\mathrm{~d})$ & 118.8 (d) & $120.6(d)$ & $28.4(q)$ & $27.9(q)$ & $26.4(q)$ & $119.3(d)$ \\
\hline 17 & $45.0(\mathrm{~d})$ & 46.3 (d) & $45.1(\mathrm{~d})$ & $45.6(d)$ & $45.5(\mathrm{~d})$ & $45.2(\mathrm{~d})$ & $45.2(\mathrm{~d})$ & $45.8(\mathrm{~d})$ & $45.6(d)$ & $44.2(\mathrm{~d})$ & 46.3 (d) \\
\hline 18 & $174.9(\mathrm{~s})$ & $173.3(\mathrm{~s})$ & $174.7(\mathrm{~s})$ & $175.3(\mathrm{~s})$ & $174.1(\mathrm{~s})$ & $174.5(\mathrm{~s})$ & $174.0(\mathrm{~s})$ & $175.1(\mathrm{~s})$ & $180.4(\mathrm{~s})$ & $176.4(\mathrm{~s})$ & $173.5(\mathrm{~s})$ \\
\hline 19 & $6.3(q)$ & $8.2(q)$ & $6.2(q)$ & $6.9(q)$ & $6.1(q)$ & $6.2(q)$ & $6.1(q)$ & $8.3(q)$ & $7.0(q)$ & $6.2(q)$ & $8.1(q)$ \\
\hline 20 & $8.8(q)$ & $11.2(q)$ & $9.3(q)$ & $18.2(q)$ & 9.7 (q) & $13.1(q)$ & $12.9(q)$ & $106.2(\mathrm{t})$ & $111.5(\mathrm{t})$ & $106.8(\mathrm{t})$ & $11.4(q)$ \\
\hline 2-OCOCCH & $170.3(\mathrm{~s})$ & $169.0(\mathrm{~s})$ & $169.7(\mathrm{~s})$ & $170.2(\mathrm{~s})$ & $169.0(\mathrm{~s})$ & $169.8(\mathrm{~s})$ & $170.0(\mathrm{~s})$ & $168.6(\mathrm{~s})$ & $172.3(\mathrm{~s})$ & $169.4(\mathrm{~s})$ & $169.3(\mathrm{~s})$ \\
\hline $2-\mathrm{OCOC} \mathrm{H}_{3}$ & $21.1(q)$ & $23.6(q)$ & $21.4(q)$ & $22.0(\mathrm{q})$ & $20.9(q)$ & $22.0(q)$ & $20.5(q)$ & $22.4(q)$ & $21.5(\mathrm{q})$ & $19.8(\mathrm{q})$ & $22.6(q)$ \\
\hline 6-OCOCHH 3 & & & $169.6(\mathrm{~s})$ & & & & & & & & \\
\hline 6-OCOC $\mathrm{H}_{3}$ & & & $21.0(\mathrm{q})$ & & & & & & & & \\
\hline 9- $\mathrm{OCOCH}_{3}$ & $170.2(\mathrm{~s})$ & $168.7(\mathrm{~s})$ & $170.2(\mathrm{~s})$ & $169.8(\mathrm{~s})$ & $169.5(\mathrm{~s})$ & & $169.4(\mathrm{~s})$ & & & & $168.9(\mathrm{~s})$ \\
\hline 9-OCOC $\mathrm{H}_{3}$ & $22.1(q)$ & $22.7(q)$ & $21.0(q)$ & $21.1(\mathrm{q})$ & $21.9(q)$ & & $21.9(q)$ & & & & $22.6(q)$ \\
\hline $12-\mathrm{OCOCH}_{3}$ & & & $170.3(\mathrm{~s})$ & & & & $169.2(\mathrm{~s})$ & & & $168.0(\mathrm{~s})$ & \\
\hline $12-\mathrm{OCOCH}_{3}$ & & & $21.9(\mathrm{q})$ & & & & $20.9(q)$ & & & $19.5(\mathrm{q})$ & \\
\hline $14-\mathrm{OCOCH}_{3}$ & & & & & & & & $169.0(\mathrm{~s})$ & $172.7(\mathrm{~s})$ & $168.9(\mathrm{~s})$ & \\
\hline $14-\mathrm{OCOCH}_{3}$ & & & & & & & & $22.1(q)$ & $21.3(\mathrm{q})$ & $19.8(\mathrm{q})$ & \\
\hline $1^{\prime}$ & & $171.2(\mathrm{~s})$ & & & $171.9(\mathrm{~s})$ & $173.1(\mathrm{~s})$ & & & & & $164.7(\mathrm{~s})$ \\
\hline $2^{\prime}$ & & $29.1(\mathrm{t})$ & & & $43.2(\mathrm{t})$ & $34.0(\mathrm{t})$ & & & & & $129.7(\mathrm{~s})$ \\
\hline $3^{\prime}$ & & $10.9(q)$ & & & $25.7(d)$ & $24.8(\mathrm{t})$ & & & & & 129.5 (d) \\
\hline $4^{\prime}$ & & & & & $22.3(q)$ & $31.4(\mathrm{t})$ & & & & & $128.5(\mathrm{~d})$ \\
\hline $5^{\prime}$ & & & & & $22.3(\mathrm{t})$ & $22.4(\mathrm{t})$ & & & & & $133.0(\mathrm{~d})$ \\
\hline $6^{\prime}$ & & & & & & $14.0(\mathrm{q})$ & & & & & $128.5(\mathrm{~d})$ \\
\hline $7^{\prime}$ & & & & & & & & & & & $129.5(\mathrm{~d})$ \\
\hline
\end{tabular}

${ }^{\mathrm{a}}$ Assignments made using the HSQC and HMBC techniques; ${ }^{\mathrm{b}}$ Recorded in Acetone- $d_{6}$ at $100 \mathrm{MHz} ;{ }^{\mathrm{c}}$ Recorded in pyridine- $d_{5}$ at $100 \mathrm{MHz} ;{ }^{\mathrm{d}}$ Recorded in $\mathrm{CD}_{3} \mathrm{OD}$ at $100 \mathrm{MHz}$. 
Figure 2. Key HMBC (arrows) and COSY (bold lines) correlations of 1, 3, 6 and $\mathbf{8 .}$

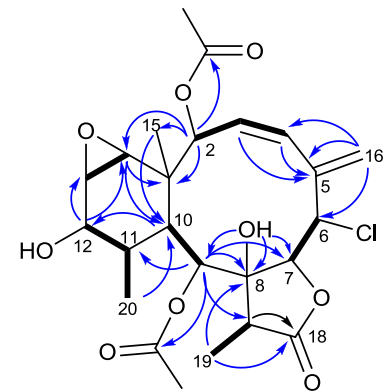

1

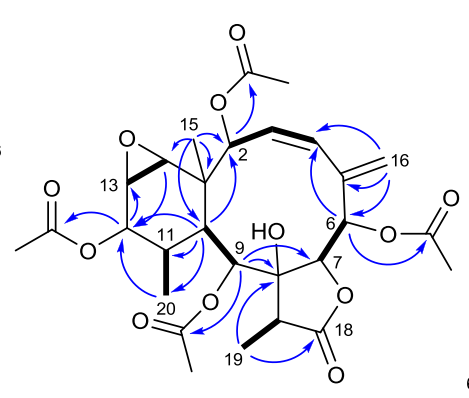

3

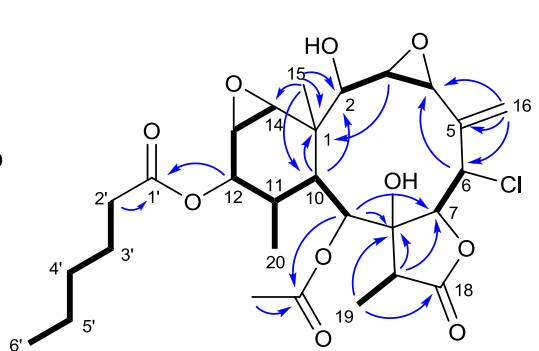

6

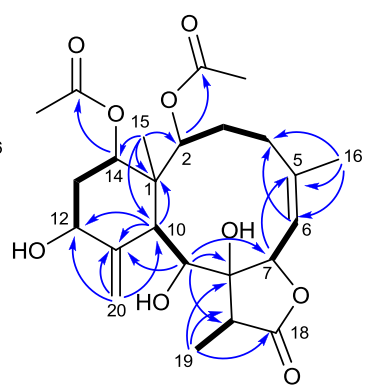

8

Figure 3. (a) Key NOESY correlations of Compound 1; (b) ORTEP (Oak Ridge Thermal Ellipsoid Plot) diagram showing the crystallographic atom-numbering scheme and solid state conformation of $\mathbf{1}$.

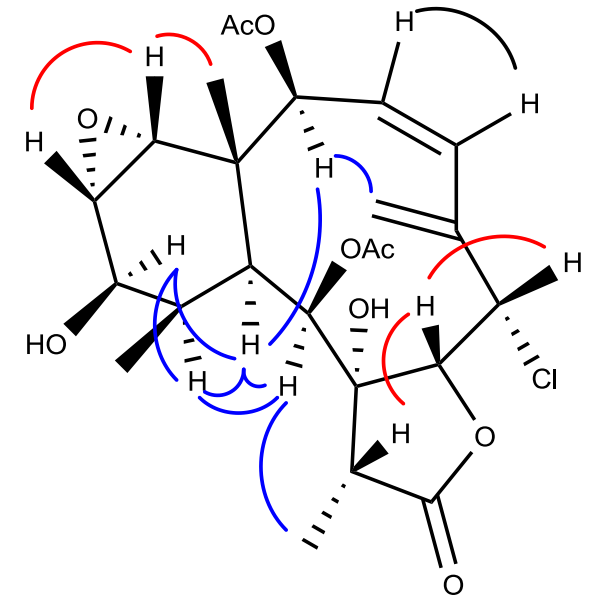

a

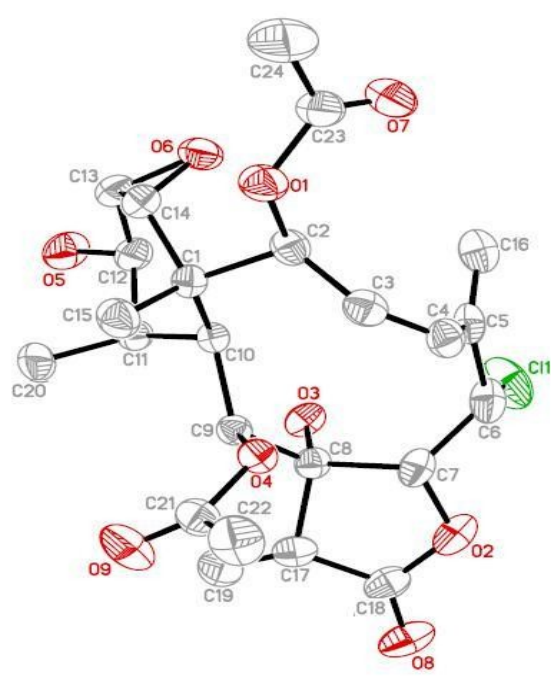

b

Briaviolide B (2) was isolated as a colorless gum, having a molecular formula of $\mathrm{C}_{27} \mathrm{H}_{35} \mathrm{O}_{10} \mathrm{Cl}$ as deduced from the high-resolution ESIMS. Similar to those of 1, Compound 2 showed IR bands at 3453, 1783, 1738 and $1732 \mathrm{~cm}^{-1}$, indicating hydroxyl, $\gamma$-lactone and ester carbonyl functionalities, respectively. Comparisons of its ${ }^{1} \mathrm{H}$ - and ${ }^{13} \mathrm{C}-\mathrm{NMR}$ data (Tables 1 and 2) with those of $\mathbf{1}$ revealed strong resemblance in all signals, except that the C-12 and H-12 signals in the NMR spectra of 2 were shifted downfield to $\delta_{\mathrm{C}} 73.7$ and $\delta_{\mathrm{H}} 4.62(\mathrm{~d}, J=4.4 \mathrm{~Hz})$, respectively, suggesting that Compound 2 had an ester group at position $\mathrm{C}-12$. This ester group was revealed to be a propionyloxy group $\left(\delta_{\mathrm{H}} 2.38, \mathrm{~m}\right.$; $\delta_{\mathrm{H}} 1.15, \mathrm{t}, J=8.0 \mathrm{~Hz}$ ). The structure of 2 was further supported by COSY, HSQC and HMBC experiments. The NOESY cross-peaks of $\mathbf{2}$ and $\mathbf{1}$ were quite similar, suggesting that they have the same relative configuration. Thus, briaviolide B (2) was established to be a 12-propionyloxy derivative of 1 .

The HRESIMS and ${ }^{13} \mathrm{C}-\mathrm{NMR}$ data (Table 2) of Compound 3 suggested a molecular formula of $\mathrm{C}_{28} \mathrm{H}_{36} \mathrm{O}_{12}$ that contains eleven degrees of unsaturation. It was found that the ${ }^{1} \mathrm{H}-,{ }^{13} \mathrm{C}-\mathrm{NMR}$ and IR spectroscopic data of $\mathbf{3}$ were very similar to those of Compound 1, except for the signals of two more 
acetyl groups, including two methyl singlets, $\delta_{\mathrm{H}} 2.07\left(\delta_{\mathrm{C}} 21.0\right), \delta_{\mathrm{H}} 2.19\left(\delta_{\mathrm{C}} 21.9\right)$, and the respective two carbonyls, $\delta_{\mathrm{C}} 169.6, \delta_{\mathrm{C}}$ 170.3. The HMBC correlations (Figure 2) of H-6 $\left(\delta_{\mathrm{H}} 5.75\right.$, d, $J=10.0 \mathrm{~Hz}) / \delta_{\mathrm{C}} 169.6$ and $\mathrm{H}-12\left(\delta_{\mathrm{H}} 4.63, \mathrm{~d}, J=5.0 \mathrm{~Hz}\right) / \delta_{\mathrm{C}} 170.3$ suggested that two acetoxyl group were attached at C- 6 and C-12. Compound 3 was the first example of a briarane-type diterpenoid that contains an ester group at C-6. The configuration of Compound 3 was determined by using NOESY correlations (Figure 4) and comparing the data with those of 1. The NOESY correlations of Me-15/Me-20, H-14; H-13/H-14 and H-7/H-17 indicated that all these atoms were $\beta$-oriented and the correlations of $\mathrm{H}-10 / \mathrm{H}-2, \mathrm{H}-9, \mathrm{H}-12 ; \mathrm{H}-12 / \mathrm{Me}-19$ suggested that all of these atoms were $\alpha$-oriented. In addition, the NOESY correlations between OH-8 $\left(\delta_{\mathrm{H}} 3.48, \mathrm{~s}\right)$ and $\mathrm{H}-6, \mathrm{H}-10, \mathrm{Me}-19$ confirmed the $\alpha$-orientation of H-6 and OH-8. On the basis of the above observations, the structure of briaviolide $\mathrm{C}$ (3) was assigned as the 2,6,9,12-tetraacetyl derivative of $\mathbf{1}$, having $1 S, 2 S, 6 R, 9 S, 10 S, 11 R, 12 R, 13 S$ and $14 R$ configurations.

Figure 4. Key NOESY correlations of Compounds 3-7 and 9.

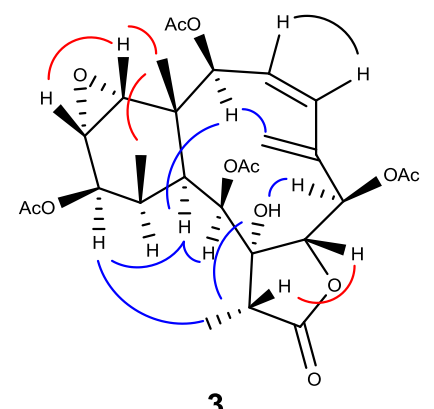

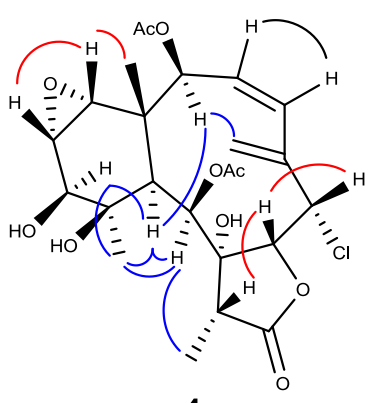

4

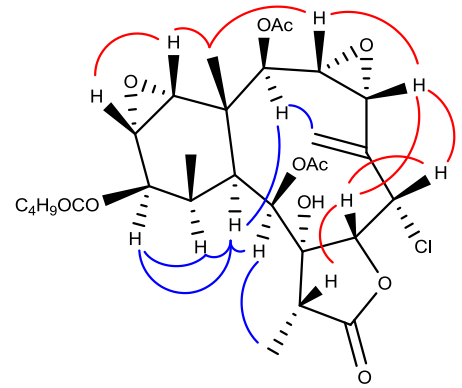

5

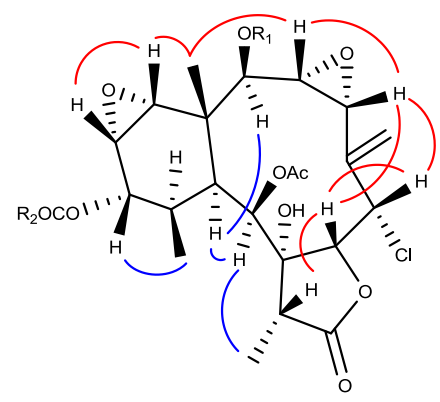

$6 \mathrm{R}_{1}=\mathrm{H}, \mathrm{R}_{2}=\mathrm{C}_{5} \mathrm{H}_{11}$ $7 R_{1}=A c, R_{2}=M e$

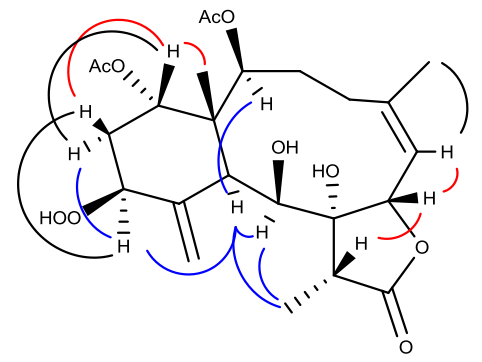

9

A pseudo-molecular ion peak at $m / z 537.1506[\mathrm{M}+\mathrm{Na}]^{+}$in the HRESIMS suggested that briaviolide $\mathrm{D}$ (4) had the molecular formula of $\mathrm{C}_{24} \mathrm{H}_{31} \mathrm{O}_{10} \mathrm{Cl}$ with nine degrees of unsaturation. The presence of a chlorine atom was supported by an isotope peak at $\mathrm{m} / \mathrm{z} 539$ in the LRESI spectrum, having one third of the intensity relative to $m / z$ 537. The NMR spectroscopic data (Tables 1 and 2) and IR spectrum revealed that Compound 4 possessed an 8-hydroxybriarane structure similar to that of Compound 1, except for one additional hydroxyl group at C-11 $\left(\delta_{\mathrm{C}} 77.0\right)$. This finding was confirmed from ${ }^{13} \mathrm{C}-\mathrm{NMR}$ data and HMBC correlations between H-10/C-11, H-12/C-11 and Me-20/C-11. The NOESY correlations of $\mathrm{H}-10 / \mathrm{Me}-11, \mathrm{H}-12$ required that the methyl group at $\mathrm{C}-11$ be $\alpha$-oriented. The configurations of other chiral centers are similar to Compound $\mathbf{1}$ as ascertained by NOESY experiments (Figure 4). Thus, the structure of briaviolide D (4) was established as $(1 S, 2 S, 6 S, 7 R, 8 R, 9 S$, 
$10 S, 11 R, 12 S, 13 S, 14 R, 17 R)$-6-chloro-13,14-epoxy-2,9-diacetoxy-8,11,12-trihydroxybriaran-3(4),5(16)dien-18,7-olide.

The HRESIMS data of 5 agreed with the molecular formula $\mathrm{C}_{29} \mathrm{H}_{39} \mathrm{O}_{11} \mathrm{Cl}$ containing a chlorine atom and 10 degrees of unsaturation. The IR bands at 3429, 1779 and $1738 \mathrm{~cm}^{-1}$ suggested the presence of hydroxyl group, ester groups and a $\gamma$-lactone moiety. A detailed inspection of ${ }^{1} \mathrm{H}$ and ${ }^{13} \mathrm{C}-\mathrm{NMR}$ spectroscopic data (Tables 1 and 2) of $\mathbf{5}$ indicated the presence of an 8-hydroxybriarane skeleton with two epoxides, two acetate esters and an isovalerate ester group. It was found that the spectroscopic data of Compound 5 were very similar to those of brianolide [23]. However, cross comparisons of ${ }^{1} \mathrm{H}$ - and ${ }^{13} \mathrm{C}$-NMR spectra showed that the 12 -acetoxyl signals in brianolide were replaced by an isovalerate ester group $\left(\delta_{\mathrm{H}} 2.20, \mathrm{~m} ; 2.10, \mathrm{~m} ; 0.96 \mathrm{~d}, 6 \mathrm{H}, J=6.3 \mathrm{~Hz}\right) ;\left(\delta_{\mathrm{C}} 171.9,43.2\right.$, 25.7, $22.3 \times 2$ ) in Compound $\mathbf{5}$. The configurations of $\mathbf{5}$ was deduced by the NOESY analysis (Figure 4) and was based on the X-ray analysis of brianolide [24]. It was observed that the introduction of the 3,4-epoxide ring on the skeleton does not affect the boat-like conformation of the macro-ring, as revealed by the same NOESY interactions between $\mathrm{H}-16 / \mathrm{H}-2$ and $\mathrm{H}-2 / \mathrm{H}-10$ as those of Compound 1. Thus, the structure of briaviolide $\mathrm{E}(\mathbf{5})$ was established as $(1 R, 2 R, 3 R, 4 R, 6 S, 7 R, 8 R, 9 S, 10 S, 11 R, 12 R$, $13 S, 14 R, 17 R$ )-6-chloro-3(4),13(14),-diepoxy-2,9-diacetoxy-12-isovaleryloxy-8-hydroxybriaran-5(16)dien-18,7-olide.

The HRESIMS of briaviolide F (6) showed a pseudo-molecular ion peak at $\mathrm{m} / \mathrm{z} 593.2125$ $[\mathrm{M}+\mathrm{Na}]^{+}$, consistent with a molecular formula of $\mathrm{C}_{28} \mathrm{H}_{39} \mathrm{O}_{10} \mathrm{Cl}(\Delta=10)$. Cross comparison of ${ }^{1} \mathrm{H}$ - and ${ }^{13} \mathrm{C}-\mathrm{NMR}$ spectroscopic data of $\mathbf{6}$ (Tables 1 and 2) with those of 5 revealed that the differences were the substituents at C-2 and configurations at C-12. Comparison of the proton chemical shift of H-2 with that of milolide D [23] (Figure 5) could confirm the presence of a hydroxyl group at C-2 $\left(\delta_{\mathrm{C}} 74.0\right)$ in 6. Signals of an acetyl group $\left(\delta_{\mathrm{H}} 2.20 ; \delta_{\mathrm{C}} 169.8,22.0\right)$ located at C-9 $\left(\delta_{\mathrm{C}} 68.7\right)$ and one hexanoate group $\left(\delta_{\mathrm{H}} 2.28,1.61,1.31,1.31,0.90 ; \delta_{\mathrm{C}} 173.1,34.0,24.8,31.4,22.4,14.0\right)$ located at $\mathrm{C}-12\left(\delta_{\mathrm{C}} 69.7\right)$ were determined by their HMBC correlations (Figure 2). The NOESY correlations (Figure 4) of $\mathrm{H}-10 / \mathrm{H}-2$ and $\mathrm{H}-9, \mathrm{H}-9 / \mathrm{Me}-19$ suggested that $\mathrm{H}-2, \mathrm{H}-9, \mathrm{H}-10$ and Me-19 were placed in $\alpha$-orientation. Correlations of H-7/H-6 and H-17, H-12/H-13 and Me-20, H-14/H-13 and Me-15 agreed with $\beta$-orientations for all these groups. Thus, Compound $\mathbf{6}$ was established as a $2 \beta$-hydroxyl-12 $\alpha$-hexanoyl derivative of 5 .

Figure 5. Selected ${ }^{1} \mathrm{H}$ - and ${ }^{13} \mathrm{C}-\mathrm{NMR}$ data of Compounds 5-7 and compared with known compounds.

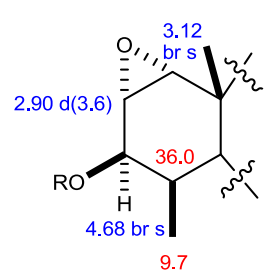

5

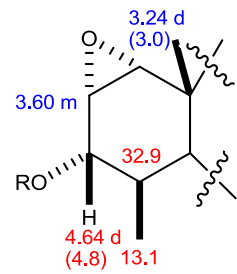

6

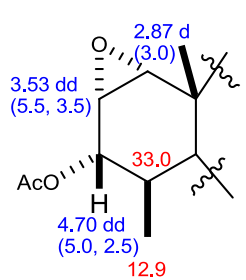

7

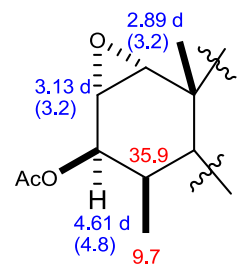

Briaexcavatolide E Solenolide D

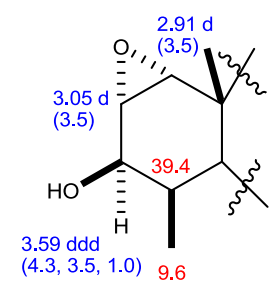

Solenolide C

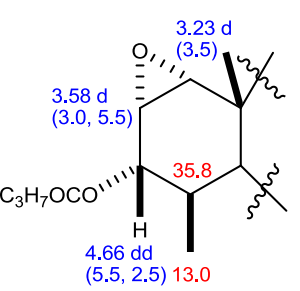

Milolide D

Briaviolide $\mathrm{G}$ (7) had the molecular formula $\mathrm{C}_{26} \mathrm{H}_{33} \mathrm{O}_{11} \mathrm{Cl}$, as determined by HRESIMS analysis. It was found that the ${ }^{1} \mathrm{H}-,{ }^{13} \mathrm{C}-\mathrm{NMR}$ (Tables 1 and 2) and IR spectroscopic data were very similar to 
those of Compound $\mathbf{6}$. However, the hexanoate group at $\mathrm{C}-12$ in $\mathbf{6}$ was replaced by an acetyl group at C-2 in 7. This finding was supported by the HMBC correlations between $\mathrm{H}-2\left(\delta_{\mathrm{H}} 5.23\right.$, d, $J=9.5 \mathrm{~Hz}) /$ carbonyl carbon $\left(\delta_{\mathrm{C}} 170.0\right)$ and $\mathrm{H}-12\left(\delta_{\mathrm{H}} 4.70, \mathrm{dd}, J=5.0,2.5 \mathrm{~Hz}\right) /$ carbonyl carbon $\left(\delta_{\mathrm{C}}\right.$ 169.4). Comparing the ${ }^{1} \mathrm{H}$ - and ${ }^{13} \mathrm{C}-\mathrm{NMR}$ data of 7 with those of solenolide $\mathrm{D}$ [25] and briaexcavatolide E [22] indicated their resemblance, except for the chemical shifts around C-12 and C-13. Based on Kobayashi's and Williams's study [26], the configuration of 12-OH could be assigned (Figure 5). By comparison of the coupling constant of $\mathrm{H}-12 / \mathrm{H}-13$ and the chemical shift of $\mathrm{C}-20$, as well as the NOESY correlation between $\mathrm{H}-12$ and Me-20 ( $\left.\delta_{\mathrm{H}} 1.06\right)$, the acetyl group at C-12 was assigned to be $\alpha$-face. The other NOSEY correlations (Figure 4) also indicated that Compound 7 had identical configurations as those of $\mathbf{6}$. Therefore, 7 was assigned a $2 \beta$-acetoxyl-12 $\alpha$-acetoxyl derivative of Compound 6.

Briaviolide H (8) was obtained as an amorphous gum. The molecular formula of $\mathbf{8}$ was determined as $\mathrm{C}_{24} \mathrm{H}_{34} \mathrm{O}_{9}$ by its HRESIMS. The IR spectrum showed absorption bands due to hydroxyl group $\left(3440 \mathrm{~cm}^{-1}\right), \gamma$-lactone $\left(1732 \mathrm{~cm}^{-1}\right)$ and ester carbonyl $\left(1712 \mathrm{~cm}^{-1}\right)$. The ${ }^{1} \mathrm{H}$ - and ${ }^{13} \mathrm{C}$-NMR spectra of 8 in $\mathrm{CDCl}_{3}$ gave broad signals, while those in acetone- $d_{6}$ were well resolved. Characteristic resonances due to three methyl protons $\left(\delta_{\mathrm{H}} 1.02, \mathrm{~d}, J=7.2 \mathrm{~Hz} ; 1.08, \mathrm{~s} ; 1.85\right.$, s; each $\left.3 \mathrm{H}\right)$ and two acetyl protons $\left(\delta_{\mathrm{H}} 1.90, \mathrm{~s}, 6 \mathrm{H}\right)$ were observed in the ${ }^{1} \mathrm{H}-\mathrm{NMR}$ spectrum (Table 1$)$. Signals of six oxygenated carbons $\left(\delta_{\mathrm{C}} 74.8,79.9,83.6,75.7,69.4,75.7\right)$, two acetyl carbons $\left(\delta_{\mathrm{C}} 168.6\right.$ and 169.0$)$ and a $\gamma$-lactone carbonyl carbon $\left(\delta_{\mathrm{C}}\right.$ 175.1) were observed in the ${ }^{13} \mathrm{C}$-NMR spectrum (Table 2). The HMBC correlations of $\mathrm{H}-2\left(\delta_{\mathrm{H}} 5.34, \mathrm{~d}, J=9.2 \mathrm{~Hz}\right) /$ carbonyl carbon $\left(\delta_{\mathrm{C}} 168.6\right)$ and $\mathrm{H}-14\left(\delta_{\mathrm{H}} 4.68\right.$, br s)/carbonyl carbon $\left(\delta_{\mathrm{C}} 169.0\right)$ helped to locate two acetoxyl groups at C-2 and C-14. The above data suggested that Compound $\mathbf{8}$ is a highly oxygenated 8-hydroxybriarane-type diterpenoid. The ${ }^{1} \mathrm{H}-\mathrm{NMR}$ spectrum of 8 was similar to that of frajunolide A [19], except that the chemical shift of $\mathrm{H}-12\left(\delta_{\mathrm{H}} 4.13\right.$, $\mathrm{dd}, J=10.8,5.2 \mathrm{~Hz}$; in $\left.\mathrm{CDCl}_{3}\right)$ was located upfield as compared with frajunolide $\mathrm{A}\left(\delta_{\mathrm{H}} 5.35\right)$. The last remaining oxygen can only be accounted for by a hydroxyl group attached on C-9, because the chemical shift of $\mathrm{H}-9\left(\delta_{\mathrm{H}} 4.68\right.$, br s) was also shifted upfield in comparison with frajunolide A $\left(\delta_{\mathrm{H}}\right.$ 5.37). The above data combined with HMBC correlations (Figure 2) revealed that 9- and 12-acetyl groups in frajunolide A were replaced by hydroxyl groups in $\mathbf{8}$. The NOESY correlations of $\mathrm{H}-2 / \mathrm{H}-10$, $\mathrm{H}-10 / \mathrm{H}-9$ and Me-19 in 8 suggested that the configurations of them were $\alpha$-oriented. On the other hand, the correlations of H-6/H-7, H-7/H-17, H-14/Me-15 agreed with a $\beta$-configuration of $\mathrm{H}-7, \mathrm{H}-14$, Me-15 and H-17. The large coupling constant $\left(J_{6,7}=9.6 \mathrm{~Hz}\right)$ confirmed the anti-parallel arrangement of H-6 and H-7 and the $\beta$-orientation of H-7 [19]. It was concluded that briaviolide $\mathrm{H}(\mathbf{8})$ has the structure of $(1 S, 2 S, 6 Z, 7 S, 8 R, 9 S, 10 S, 12 S, 14 S, 17 R)$-2,14-diacetoxy-12-hydroxy-8,9-dihydroxybriaran-5 (6)-dien-18,7-olide.

The molecular formula $\mathrm{C}_{24} \mathrm{H}_{34} \mathrm{O}_{10}$ was assigned to Compound 9 from its HRESIMS and ${ }^{13} \mathrm{C}$ NMR data (Table 2). The spectroscopic values of $\mathbf{9}$ suggested a briarane structure similar to that of $\mathbf{8}$ with one additional hydroperoxy group at C-12 $\left(\delta_{\mathrm{C}} 83.8\right)$. The configuration of Compound 9 was further determined by the NOESY experiments (Figure 4), and the correlations revealed that 9 possessed the same relative configurations as those of $\mathbf{8}$. Thus, briaviolide I (9) was assigned as 12-hydroperoxyl derivative of Compound $\mathbf{8}$.

Briaviolide $\mathrm{J}(\mathbf{1 0})$ had the molecular formula $\mathrm{C}_{26} \mathrm{H}_{36} \mathrm{O}_{10}$, as determined by its HRESIMS and DEPT ${ }^{13} \mathrm{C}$ NMR data. The IR absorptions of 10 were found at 3426,1732 and $1675 \mathrm{~cm}^{-1}$, which indicated the 
presence of hydroxyl, a $\gamma$-lactone and ester groups. The ${ }^{1} \mathrm{H}$ - and ${ }^{13} \mathrm{C}$-NMR data (Tables 1 and 2) revealed that $\mathbf{1 0}$ was an 8-hydroxybriarane-type diterpenoid and was structurally similar to 8 and $\mathbf{9 .}$ Comparisons of their NMR and MS data showed that the only difference between $\mathbf{8}$ and $\mathbf{1 0}$ was the presence of an acetate group at $\mathrm{C}-12$ in 10. Acetylation of $\mathbf{8}$ afforded a product identical to Compound 10. Thus, it was concluded that $\mathbf{1 0}$ is 12 -acetoxyl derivative of Compound $\mathbf{8}$.

In addition, six known briaranes, solenolides A and D [25], excavatolide A [26], briaexcavatolide I [22], 4ß-acetoxy-9-deacetystylatulide lactone and 9-deacetylstylatulide lactone [27], were identified. The new isolated briaranes 1-10 and derivative $\mathbf{1 1}$ were evaluated for anti-inflammatory activities on superoxide-anion generation and elastase release by human neutrophils in response to $N$-formyl-methionyl-leucyl-phenylalanine (fMLP)/Cytochalasin B (CB). The inhibition percentages of these compounds at the concentration of $10 \mu \mathrm{g} / \mathrm{mL}$ are summarized in Table 3 . The bioassay data showed that Compounds $\mathbf{5}$ and $\mathbf{9}$ have moderate activities on both of superoxide-anion generation and elastase release, while Compound $\mathbf{1 1}$ has selective activity on the inhibition of elastase release.

Table 3. Inhibitory effects of Compounds 1-11 on superoxide anion generation and elastase release by human neutrophils in response to $\mathrm{fMLP} / \mathrm{CB}$.

\begin{tabular}{ccc}
\hline \multirow{2}{*}{ Compound } & \multicolumn{2}{c}{ Inhibition (\%) $\mathbf{a}^{\mathbf{a}}$} \\
\cline { 2 - 3 } & Superoxide Anion & Elastase Release \\
\hline $\mathbf{1}$ & $6.09 \pm 1.40^{*}$ & $11.04 \pm 7.22$ \\
$\mathbf{2}$ & $6.43 \pm 2.17^{*}$ & $13.43 \pm 2.66^{* *}$ \\
$\mathbf{3}$ & $16.87 \pm 4.86^{*}$ & $6.40 \pm 4.29$ \\
$\mathbf{4}$ & $4.48 \pm 1.47^{*}$ & $9.31 \pm 6.64$ \\
$\mathbf{5}$ & $34.17 \pm 0.79^{* * *}$ & $26.03 \pm 9.51$ \\
$\mathbf{6}$ & $17.35 \pm 6.91$ & $14.34 \pm 5.28$ \\
$\mathbf{7}$ & $3.25 \pm 2.35$ & $16.66 \pm 3.12 * *$ \\
$\mathbf{8}$ & $6.01 \pm 4.16$ & $18.78 \pm 2.29 * *$ \\
$\mathbf{9}$ & $28.66 \pm 1.99 * * *$ & $28.81 \pm 6.37 *$ \\
$\mathbf{1 0}$ & $11.64 \pm 3.92 *$ & $14.62 \pm 4.41 * *$ \\
$\mathbf{1 1}$ & $6.09 \pm 4.09 * *$ & $28.60 \pm 7.54 *$ \\
genistein $^{\mathrm{b}}$ & $65.05 \pm 6.12$ & $52.45 \pm 6.34$ \\
\hline
\end{tabular}

a At a concentration of $10 \mu \mathrm{g} / \mathrm{mL}$ for each compound. Results are presented as the mean $\pm \mathrm{SEM}$ $(n=3) . * p<0.05, * * p<0.01, * * * p<0.001$ compared with the control value; ${ }^{\mathrm{b}}$ Positive control.

\section{Experimental Section}

\subsection{General Experimental Procedures}

The melting point was measured on a BÜCHI Melting Point B-540 apparatus (Buchi, Flawil, Switzerland) and uncorrected. Optical rotations were recorded on a JASCO DIP-1020 polarimeter (Jasco, Tokyo, Japan). IR spectra were measured on a JASCO FT/IR-4100 spectrophotometer (Jasco, Tokyo, Japan). HR-ESI-MS were taken on a JEOL JMS-HX 110 mass spectrometer (Jeol, Tokyo, Japan). The NMR spectra were recorded either on a Bruker Avance 300, or a 400 NMR spectrometer, or on a Varian MR 400 NMR spectrometer (Varian, Santa Clara, CA, USA). The chemical shifts were given in $\delta(\mathrm{ppm})$ and coupling constants in Hz. Silica gel 60 (Merck, Darmstadt, Germany) was used 
for column chromatography (CC), and pre-coated silica gel plates (Merck, Darmstadt, Germany, Kieselgel 60 F-254, $1 \mathrm{~mm}$ ) were used for preparative TLC. Sephadex LH-20 (Amersham Pharmacia Biotech AB, Sweden) was used for separation. LiChrospher ${ }^{\circledR}$ Si 60 (5 $\mu \mathrm{m}, 250-10$, Merck, Darmstadt, Germany) and LiChrospher ${ }^{\circledR} 100$ RP-18e (5 $\mu \mathrm{m}, 250-10$, Merck, Darmstadt, Germany) were used for NP-HPLC and RP-HPLC (Merck, Darmstadt, Germany), respectively.

\subsection{Animal Material}

The gorgonian, Briareum violacea (Quoy and Gaimard), was collected in Pingtong County of southern Taiwan by scuba diving at a depth of $15 \mathrm{~m}$, in May 2007. The fresh gorgonian was immediately frozen after collection and kept at $-20{ }^{\circ} \mathrm{C}$ until being processed. A voucher specimen was deposited in the School of Pharmacy, College of Medicine, National Taiwan University.

\subsection{Extraction and Isolation}

The gorgonian, $B$. violacea (wet weight, $2.5 \mathrm{~kg}$ ), was minced and extracted with acetone $/ \mathrm{MeOH}$ $(3 \times 5 \mathrm{~L})$ at room temperature, and the extracts were combined and concentrated under vacuum. The dark green crude residue was partitioned between EtOAc and $\mathrm{H}_{2} \mathrm{O}$ (1:1). The EtOAc-soluble portion was shaken with $n$-hexane/ $\mathrm{MeOH} / \mathrm{H}_{2} \mathrm{O}$ (4:3:1), and the $\mathrm{MeOH}$ layer (15 g) was evaporated and separated on Sephadex LH-20 to give eight fractions (L1 to L8). Fraction L3 (9.5 g) was subjected to flash column chromatography using silica gel and a gradient of $n$-hexane/EtOAc/MeOH to obtain 25 fractions (L3-1 to L3-25). Crystallization of L3-16 (n-hexane/EtOAc, 2:1; $640 \mathrm{mg}$ ) furnished 9-deacetylstylatulide lactone $(123 \mathrm{mg})$. The $\mathrm{MeOH}$-soluble portion of fraction L3-16 was separated on $\mathrm{C}_{18}$ reversed-phase (RP) HPLC using $\mathrm{MeOH} / \mathrm{H}_{2} \mathrm{O} / \mathrm{CH}_{3} \mathrm{CN}$ (50:45:10) to yield Compound 5 (9 mg), excavatolide A $(6.5 \mathrm{mg})$ and stylatulide lactone $(2 \mathrm{mg})$. Fraction L3-17 ( $n$-hexane/EtOAc, 3:2; $1.6 \mathrm{~g}$ ) was separated by RP-HPLC using $\mathrm{MeOH} / \mathrm{H}_{2} \mathrm{O} / \mathrm{CH}_{3} \mathrm{CN}$ (50:50:5) to afford Compound 6 (8.7 mg). Fraction L3-18 ( $n$-hexane/EtOAc, $1: 1 ; 2.0 \mathrm{~g}$ ) was subjected to column chromatography using silica gel and a gradient of $n$-hexane/EtOAc/MeOH to obtain 10 fractions (L3-18-1 to L3-18-10). Fraction L3-18-2 (185 mg) was subjected to RP-HPLC using $\mathrm{MeOH} / \mathrm{H}_{2} \mathrm{O} / \mathrm{CH}_{3} \mathrm{CN}$ (65:30:5) to give Compounds 2 (3.5 mg), 3 (3.8 mg) and solenolide A (7.8 mg). Fraction L3-18-4 (231 mg) was separated by RP-HPLC using $\mathrm{MeOH} / \mathrm{H}_{2} \mathrm{O} / \mathrm{CH}_{3} \mathrm{CN}$ (65:30:5) to afford Compound 8 (11.0 mg) and solenolide D (9.4 mg). Fraction L3-18-7 was subjected on RP-HPLC using $\mathrm{MeOH} / \mathrm{H}_{2} \mathrm{O} / \mathrm{CH}_{3} \mathrm{CN}$ (55:45:5) to obtain Compounds $1(12 \mathrm{mg}), 7(28 \mathrm{mg})$ and briaexcavatolide I $(5.4 \mathrm{mg})$. Fraction L3-18-8 (64 mg) was purified by RP-HPLC using $\mathrm{MeOH} / \mathrm{H}_{2} \mathrm{O} / \mathrm{CH}_{3} \mathrm{CN}$ (65:30:5) to yield Compound 10 (10.5 mg). Fraction L3-20 ( $n$-hexane/EtOAc, 1:2; $300 \mathrm{mg}$ ) was purified by RP-HPLC to afford Compounds 4 (3.5 mg) and 9 (4.3 mg).

Briaviolide A (1): Colorless amorphous prism; mp. 174-175 ${ }^{\circ} \mathrm{C} ;[\alpha]_{\mathrm{D}}^{24}-79\left(c 0.5, \mathrm{CH}_{2} \mathrm{Cl}_{2}\right)$; IR $v_{\max }$ 3524, 3365, 2980, 2949, 1767, 1737, 1375, $1231 \mathrm{~cm}^{-1} ;{ }^{1} \mathrm{H}-\mathrm{NMR}$ data (300 $\mathrm{MHz}, \mathrm{CDCl}_{3}$ ), see Table 1; ${ }^{13} \mathrm{C}$-NMR data $\left(75 \mathrm{MHz}, \mathrm{CDCl}_{3}\right)$, see Table 2; ESIMS $m / z 521[\mathrm{M}+\mathrm{Na}]^{+}, 523[\mathrm{M}+\mathrm{Na}+2]^{+}$; HRESIMS $m / z 521.1554[\mathrm{M}+\mathrm{Na}]^{+}$(calcd. for $\mathrm{C}_{24} \mathrm{H}_{31}{ }^{35} \mathrm{ClO}_{9} \mathrm{Na}, 521.1557$ ).

Briaviolide B (2): Colorless amorphous gum; $[\alpha]_{\mathrm{D}}^{24}-45\left(c 0.1, \mathrm{CH}_{2} \mathrm{Cl}_{2}\right)$; IR $v_{\max } 3453,2965,2942$, 1783, 1738, 1732, $1278 \mathrm{~cm}^{-1} ;{ }^{1} \mathrm{H}-\mathrm{NMR}$ data $\left(400 \mathrm{MHz}, \mathrm{CDCl}_{3}\right)$, see Table 1 ; ${ }^{13} \mathrm{C}-\mathrm{NMR}$ data 
$\left(100 \mathrm{MHz}, \mathrm{CDCl}_{3}\right)$, see Table 2; ESIMS $m / z 577[\mathrm{M}+\mathrm{Na}]^{+}, 579[\mathrm{M}+\mathrm{Na}+2]^{+}$; HRESIMS $m / z 577.1812[\mathrm{M}+\mathrm{Na}]^{+}$(calcd. for $\mathrm{C}_{27} \mathrm{H}_{35}{ }^{35} \mathrm{ClO}_{10} \mathrm{Na}, 577.1816$ ).

Briaviolide C (3): Colorless powder; $[\alpha]_{\mathrm{D}}^{24}-6\left(c 0.1, \mathrm{CH}_{2} \mathrm{Cl}_{2}\right)$; IR $v_{\max } 3429,2965,2928,1776$, 1738, 1373, $1213 \mathrm{~cm}^{-1}$; ${ }^{1} \mathrm{H}-\mathrm{NMR}$ data $\left(400 \mathrm{MHz}, \mathrm{CDCl}_{3}\right)$, see Table $1 ;{ }^{13} \mathrm{C}-\mathrm{NMR}$ data $(100 \mathrm{MHz}$, $\mathrm{CDCl}_{3}$ ), see Table 2; ESIMS $m / z 587[\mathrm{M}+\mathrm{Na}]^{+}$; HRESIMS $m / z 587.2101[\mathrm{M}+\mathrm{Na}]^{+}$(calcd. for $\mathrm{C}_{28} \mathrm{H}_{36} \mathrm{O}_{12} \mathrm{Na}$, 587.2104).

Briaviolide D (4): Colorless amorphous gum; $[\alpha]_{\mathrm{D}}^{24}-11\left(c 0.4, \mathrm{CH}_{2} \mathrm{Cl}_{2}\right)$; IR $v_{\max } 3433,3015,2989$, 2938, 1776, 1734, 1373, 1220, 1019, $756 \mathrm{~cm}^{-1}$; ${ }^{1} \mathrm{H}-\mathrm{NMR}$ data $\left(400 \mathrm{MHz}, \mathrm{CDCl}_{3}\right)$, see Table 1; ${ }^{13} \mathrm{C}$-NMR data $\left(100 \mathrm{MHz}, \mathrm{CDCl}_{3}\right)$, see Table 2; ESIMS $m / z 537[\mathrm{M}+\mathrm{Na}]^{+}, 539[\mathrm{M}+\mathrm{Na}+2]^{+}$; HRESIMS $m / z 537.1506[\mathrm{M}+\mathrm{Na}]^{+}$(calcd. for $\mathrm{C}_{24} \mathrm{H}_{31}{ }^{35} \mathrm{ClO}_{10} \mathrm{Na}, 537.1503$ ).

Briaviolide E (5): Colorless amorphous powder; $[\alpha]_{\mathrm{D}}^{24}-6\left(c 0.1, \mathrm{CH}_{2} \mathrm{Cl}_{2}\right)$; IR $v_{\max } 3429,2965,2928$, 1779, 1738, 1373, $1213 \mathrm{~cm}^{-1} ;{ }^{1} \mathrm{H}-\mathrm{NMR}$ data $\left(400 \mathrm{MHz}, \mathrm{CDCl}_{3}\right)$, see Table $1 ;{ }^{13} \mathrm{C}-\mathrm{NMR}$ data $\left(100 \mathrm{MHz}, \mathrm{CDCl}_{3}\right)$, see Table 2; ESIMS $m / z 612[\mathrm{M}+\mathrm{Na}]^{+}, 614[\mathrm{M}+\mathrm{Na}+2]^{+}$; HRESIMS $m / z 612.2075[\mathrm{M}+\mathrm{Na}]^{+}$(calcd. for $\mathrm{C}_{29} \mathrm{H}_{39}{ }^{35} \mathrm{ClO}_{11} \mathrm{Na}, 612.2079$ ).

Briaviolide F (6): Colorless amorphous gum; $[\alpha]_{\mathrm{D}}^{24}+16\left(c 0.4, \mathrm{CH}_{2} \mathrm{Cl}_{2}\right)$; IR $v_{\max } 3410,2981,2938$, 1768, 1742, 1369, 1216, 1019, $756 \mathrm{~cm}^{-1} ;{ }^{1} \mathrm{H}-\mathrm{NMR}$ data $\left(300 \mathrm{MHz}, \mathrm{CDCl}_{3}\right)$, see Table $1 ;{ }^{13} \mathrm{C}-\mathrm{NMR}$ data $\left(75 \mathrm{MHz}, \mathrm{CDCl}_{3}\right.$ ), see Table 2; ESIMS $m / z 593[\mathrm{M}+\mathrm{Na}]^{+}, 595[\mathrm{M}+\mathrm{Na}+2]^{+}$; HRESIMS $m / z 593.2125[\mathrm{M}+\mathrm{Na}]^{+}$(calcd. for $\mathrm{C}_{28} \mathrm{H}_{39}{ }^{35} \mathrm{ClO}_{10} \mathrm{Na}, 593.2129$ ).

Briaviolide G (7): Colorless amorphous gum; $[\alpha]_{\mathrm{D}}^{24}-18\left(c 0.6, \mathrm{CH}_{2} \mathrm{Cl}_{2}\right)$; IR $v_{\max } 3544,3447,2981$, 2937, 1782, 1739, 1375, 1223, 1021, $737 \mathrm{~cm}^{-1}$; ${ }^{1} \mathrm{H}-\mathrm{NMR}$ data $\left(400 \mathrm{MHz}, \mathrm{CDCl}_{3}\right)$, see Table 1; ${ }^{13} \mathrm{C}-\mathrm{NMR}$ data $\left(100 \mathrm{MHz}, \mathrm{CDCl}_{3}\right)$, see Table 2; ESIMS $m / z 579[\mathrm{M}+\mathrm{Na}]^{+}, 581[\mathrm{M}+\mathrm{Na}+2]^{+}$; HRESIMS $m / z 579.1605[\mathrm{M}+\mathrm{Na}]^{+}$(calcd. for $\mathrm{C}_{26} \mathrm{H}_{33}{ }^{35} \mathrm{ClO}_{11} \mathrm{Na}, 579.1609$ ).

Briaviolide H (8): Colorless amorphous gum; $[\alpha]_{\mathrm{D}}^{24}+53\left(c 0.2, \mathrm{CH}_{2} \mathrm{Cl}_{2}\right)$; IR $v_{\max } 3440,2923,1732$, 1712, 1644, 1375, 1260, 1034, 953, $733 \mathrm{~cm}^{-1} ;{ }^{1} \mathrm{H}-\mathrm{NMR}$ data (400 MHz, Acetone- $\left.d_{6}\right)$, see Table 1; ${ }^{13} \mathrm{C}-\mathrm{NMR}$ data $\left(100 \mathrm{MHz}\right.$, Acetone- $\left.d_{6}\right)$, see Table 2; ESIMS $m / z 489[\mathrm{M}+\mathrm{Na}]^{+}$; HRESIMS $m / z 489.2106[\mathrm{M}+\mathrm{Na}]^{+}$(calcd. for $\mathrm{C}_{24} \mathrm{H}_{34} \mathrm{O}_{9} \mathrm{Na}, 489.2101$ ).

Briaviolide I (9): Colorless amorphous powder; $[\alpha]_{\mathrm{D}}^{24}+20\left(c 0.4, \mathrm{CH}_{2} \mathrm{Cl}_{2}\right)$; IR $v_{\max } 3425,2928,1738$, 1715, 1373, $1259 \mathrm{~cm}^{-1}$; ${ }^{1} \mathrm{H}-\mathrm{NMR}$ data $\left(400 \mathrm{MHz}, \mathrm{CD}_{3} \mathrm{OD}\right)$, see Table 1; ${ }^{13} \mathrm{C}-\mathrm{NMR}$ data $\left(100 \mathrm{MHz}, \mathrm{CD}_{3} \mathrm{OD}\right)$, see Table 2; ESIMS $m / z 505[\mathrm{M}+\mathrm{Na}]^{+}$; HRESIMS $m / z 505.2046[\mathrm{M}+\mathrm{Na}]^{+}$ (calcd. for $\mathrm{C}_{24} \mathrm{H}_{34} \mathrm{O}_{10} \mathrm{Na}, 505.2050$ ).

Briaviolide J (10): Colorless amorphous gum; $[\alpha]_{\mathrm{D}}^{24}+50\left(c 0.1, \mathrm{CH}_{2} \mathrm{Cl}_{2}\right)$; IR $v_{\max } 3426,2927,2853$, 1732, 1675, 1375, 1257, 1044, $737 \mathrm{~cm}^{-1} ;{ }^{1} \mathrm{H}-\mathrm{NMR}$ data (400 MHz, pyridine- $\left.d_{5}\right)$, see Table 1; ${ }^{13} \mathrm{C}-\mathrm{NMR}$ data $\left(100 \mathrm{MHz}\right.$, pyridine- $\left.d_{5}\right)$, see Table 2; ESIMS $\mathrm{m} / z$ $531[\mathrm{M}+\mathrm{Na}]^{+}$; HRESIMS $m / z 531.2204[\mathrm{M}+\mathrm{Na}]^{+}$(calcd. for $\mathrm{C}_{26} \mathrm{H}_{36} \mathrm{O}_{10} \mathrm{Na}, 531.2206$ ).

Benzyl briaviolide A (11): Colorless amorphous gum; $\alpha]_{\mathrm{D}}^{24}-21\left(c 0.2, \mathrm{CH}_{2} \mathrm{Cl}_{2}\right)$; IR $v_{\max } 3463$, 2985, 2938, 1779, 1734, 1270, $1224 \mathrm{~cm}^{-1}$; ${ }^{1} \mathrm{H}-\mathrm{NMR}$ data $\left(300 \mathrm{MHz}, \mathrm{CDCl}_{3}\right)$, see Table 1; ${ }^{13} \mathrm{C}$-NMR data $\left(75 \mathrm{MHz}, \mathrm{CDCl}_{3}\right.$ ); see Table 2; ESIMS $m / z 625[\mathrm{M}+\mathrm{Na}]^{+}, 627[\mathrm{M}+\mathrm{Na}+2]^{+}$; HRESIMS $m / z 625.1820[\mathrm{M}+\mathrm{Na}]^{+}$(calcd. for $\mathrm{C}_{31} \mathrm{H}_{35}{ }^{35} \mathrm{ClO}_{10} \mathrm{Na}, 625.1816$ ). 


\subsection{Benzoylation of Briaviolide (1)}

Compound 1 ( $3.0 \mathrm{mg})$ was stirred with $0.1 \mathrm{~mL}$ of benzoyl chloride in pyridine $(1.0 \mathrm{~mL})$ for $20 \mathrm{~h}$ at room temperature. After evaporation, the residue was separated by a $\mathrm{C}_{18}$ reversed-phase HPLC column $\left(\mathrm{MeOH} / \mathrm{H}_{2} \mathrm{O}, 4: 1\right)$ to give pure Compound 11 (2.8 mg).

\subsection{Single Crystal X-Ray Structure Determination of Briaviolide (1)}

A suitable colorless crystal $\left(0.20 \times 0.15 \times 0.10 \mathrm{~mm}^{3}\right)$ of $\mathbf{1}$ for diffraction was obtained by simple evaporation from methanol solution. Crystal data: $\mathrm{C}_{24} \mathrm{H}_{31} \mathrm{ClO}_{9}$, orthorhombic, $a=10.4634(2) \AA$, $b=13.9191(3) \AA, c=17.1825(3) \AA, \quad V=2502.48(8) \AA^{3}$, space group $\mathrm{P} 2{ }_{1} 2_{1} 2_{1}, Z=4$, $\mathrm{D}_{\text {calcd }}=1.324 \mathrm{Mg} / \mathrm{m}^{3}, \lambda=1.54178 \AA, \mu(\mathrm{Mo} \mathrm{K} \alpha) 1.783 \mathrm{~mm}^{-1}, \mathrm{~F}(000)=1056, \mathrm{~T}=295(2) \mathrm{K}$. A total of 17,948 reflections were collected, of which 4536 unique reflections $\left(R_{\text {int }}=0.0427\right)$ with $\mathrm{I}>2 \sigma(I)$ were used for the analysis. The data was solved using the direct method, and the structure was refined by a full-matrix least-squares procedure on $\mathrm{F}^{2}$ values. All non-hydrogen atoms were refined with anisotropic thermal parameters. The hydrogen atom positions were geometrically idealized and allowed to ride on their parent atoms. The final indices were R1 0.0499, wR2 0.1420 with goodness-of-fit $=1.149$. The final X-ray molecular model is shown in Figure $3 \mathrm{~b}$.

\subsection{Anti-Inflammatory Assays}

\subsubsection{Human Neutrophils Elastase Release}

Degranulation of azurophilic granules was determined by elastase release, as described previously [28]. Experiments were performed using MeO-Suc-Ala-Ala-Pro-Val-p-nitroanilide as the elastase substrate. After supplementation with MeO-Suc-Ala-Ala-Pro-Val-p-nitroanilide (100 $\mu \mathrm{M})$, neutrophils $\left(6 \times 10^{5}\right.$ cell $\left./ \mathrm{mL}\right)$ were equilibrated at $37{ }^{\circ} \mathrm{C}$ for 2 min and incubated with each test compound for $5 \mathrm{~min}$. Cells were activated by fMLP $(100 \mathrm{nM}) / \mathrm{CB}(0.5 \mu \mathrm{g} / \mathrm{mL})$, and changes in absorbance at $405 \mathrm{~nm}$ were monitored continuously for elastase release. The results are expressed as the percentage of the initial rate of elastase release in the fMLP/CB-activated, test compound-free (DMSO) control system.

\subsubsection{Human Neutrophil Superoxide Generation}

Human neutrophils were obtained by means of dextran sedimentation and Ficoll centrifugation. Superoxide anion production was assayed by monitoring the superoxide dismutase-inhibitable reduction of ferricytochrome $c$ [29]. In brief, after supplementation with $0.5 \mathrm{mg} / \mathrm{mL}$ ferricytochrome $c$ and $1.0 \mathrm{mM} \mathrm{Ca}^{2+}$, neutrophils were equilibrated at $37^{\circ} \mathrm{C}$ for $2 \mathrm{~min}$ and incubated with drugs for $5 \mathrm{~min}$. Cells were activated with $100 \mathrm{nM}$ fMLP for $10 \mathrm{~min}$. When fMLP was used as a stimulant, CB ( $1 \mu \mathrm{g} / \mathrm{mL}$ ) was incubated for $3 \mathrm{~min}$ before activation by the peptide (fMLP/CB). Changes in absorbance with the reduction of ferricytochrome $c$ at $550 \mathrm{~nm}$ were continuously monitored in a double-beam, six-cell positioner spectrophotometer with constant stirring (Hitachi U-3010, Tokyo, Japan). Calculations were based on differences in the reactions with and without SOD $(100 \mathrm{U} / \mathrm{mL})$ divided by the extinction coefficient for the reduction of ferricytochrome $c$. 


\section{Conclusions}

Sixteen briarane diterpenoids, including ten new compounds briaviolides, A-J (1-10), were successfully isolated from the Taiwanese soft coral, Briareum violacea, and their structures determined. The inhibitory effects of the isolates and new derivative $\mathbf{1 1}$ on superoxide-anion generation and elastase release by human neutrophils in response to fMLP/CB were evaluated. Compounds 5 and 9 showed moderate anti-inflammatory activities at a concentration of $10 \mu \mathrm{g} / \mathrm{mL}$. Compound 11, derived from Compound 1, showed better inhibition of elastase release than that of $\mathbf{1}$. Further comparison of the activities of those compounds may suggest that $\beta$-orientation and the chain length of ester groups at C-12 are important for the anti-inflammatory activities in briarane-type diterpenoids.

\section{Acknowledgments}

We thank Yi-Hung Liu, Instrumentation Center, National Taiwan University for providing X-ray crystallographic data. The financial support (NSC 98-2113-M-002-002-MY2) from the National Science Council, Taiwan, is also acknowledged.

\section{Author Contributions}

Ya-Ching Shen led the research team and supervised Ph.D. students, Chia-Ching Liaw, Yuan-Bin Cheng and Yun-Sheng Lin. Chia-Ching Liaw isolated the metabolites, measured various spectra and determined the structures. Yun-Sheng Lin and Chia-Ching Liaw collected the materials. Tsong-Long Hwang and Yao-Haur Kuo tested the biological activities. Ya-Ching Shen prepared the manuscript. Yuan-Bin Cheng edited the manuscript.

\section{Conflicts of Interest}

The authors declare no conflict of interest.

\section{References}

1. Bhakuni, D.S.; Rawat, D.S. Bioactive Marine Natural Products; Springer: New York, NY, USA, 2005.

2. Shin, J.; Park, M.; Fenical, W. The junceellolides, new anti-inflammatory diterpenoids of the briarane class from the Chinese gorgonian Junceella fragilis. Tetrahedron 1989, 45, 1633-1638.

3. Rodriguez, A.D. The natural products chemistry of west India gorgonian octocorals. Tetrahedron 1995, 51, 4571-4618.

4. Rodriguez, J.; Nieto, R.M.; Jimenez, C. New briarane stecholide diterpenes from the Indonesian gorgonian Briareum sp. J. Nat. Prod. 1998, 61, 313-317.

5. Sung, P.J.; Su, J.H.; Wang, G.H.; Lin, S.F.; Duh, C.Y.; Sheu, J.H. Excavatolides F-M, new briarane diterpenes from the gorgonian Briareum excavatum. J. Nat. Prod. 1999, 62, 457-463. 
6. Wu, S.L.; Sung, P.J.; Chiang, M.Y.; Wu, J.Y.; Sheu, J.H. New polyoxygenated briarane diterpenoids, briaexcavatolides $\mathrm{O}-\mathrm{R}$, from the gorgonian Briareum excavatum. J. Nat. Prod. 2001, 64, 1415-1420.

7. Keifer, P.A.; Rinehart, K.L.; Hooper, I.R. Renillafoulins, antifouling diterpenes from the sea pansy Renilla reniformis (Octocorallia). J. Org. Chem. 1986, 51, 4450-4454.

8. Qi, S.H.; Zhang, S.; Qian, P.Y.; Xiao, Z.H.; Li, M.Y. Ten new antifouling briarane diterpenoids from the south China sea gorgonian Junceella juncea. Tetrahedron 2006, 62, 9123-9130.

9. Grode, S.H.; James, T.R., Jr.; Cardellina, J.H., II. Molecular structures of the briantheins, new insecticidal diterpenes from Briareum polyanthes. J. Org. Chem. 1983, 48, 5203-5207.

10. Hamann, M.T.; Harrison, K.N.; Carroll, A.R.; Scheuer, P.J. Briarane diterpenes from Micronesian gorgonians. Heterocycles 1996, 42, 325-331.

11. Aoki, S.; Okano, M.; Matsui, K.; Itoh, T.; Satari, R.; Akiyama, S.; Kobayashi, M. Brianthein A, a novel briarane-type diterpene reversing multidrug resistance in human carcinoma cell line, from the gorgonian Briareum excavatum. Tetrahedron 2001, 57, 8951-8957.

12. Rodriguez, A.D.; Ramirez, C.; Cobar, O.M. Briareins C-L, 10 new briarane diterpenoids from the common Caribbean gorgonian Briareum asbestinum. J. Nat. Prod. 1996, 59, 15-22.

13. Burk, J.E.; Helm, D.V.D.; Chang, C.Y.; Ciereszko, L.S. The crystal and molecular structure of briarein A, a diterpenoid from the gorgonian Briareum asbestinum. Acta Cryst. 1977, B33, 704-709.

14. Sung, P.J.; Sheu, J.H.; Xu, J.P. Survey of briarane-type diterpenoid of marine origin. Heterocycle 2002, 56, 535-579.

15. Sung, P.J.; Chang, P.C.; Fang, L.S.; Sheu, J.H.; Chen, W.C.; Chen, Y.P.; Lin, M.R. Suvery of briarane-related diterpenoids-Part II. Heterocycles 2005, 65, 195-204.

16. Sung, P.J.; Gwo, H.H.; Fan, T.Y.; Li, J.J.; Dong, J.; Han, C.C.; Wu, L.S.; Fang L.S. Natural product chemistry of gorgonian corals of the genus Junceella Biochem. Syst. Ecol. 2004, 32, 185-196.

17. Shen, Y.C.; Lin, Y.C.; Chiang, M.Y. Juncenolide A, a new briarane from the Taiwanese gorgonian Junceella juncea. J. Nat. Prod. 2002, 65, 54-56.

18. Shen, Y.C.; Lin, Y.C.; Huang, Y.L. Juncenolide E, a new briarane from Taiwanese gorgonian Junceella juncea. J. Chin. Chem. Soc. (Taipei) 2003, 50, 1267-1270.

19. Shen, Y.C.; Chen, Y.H.; Hwang, T.L.; Guh, J.H.; Khalil, A.T. Four new briarane diterpenoids from the gorgonian coral Junceella fragilis. Helv. Chim. Acta 2007, 90, 1391-1398.

20. Liaw, C.C.; Shen, Y.C.; Lin, Y.S.; Hwang, T.L.; Kuo, Y.H.; Khalil, A.T. Frajunolides E-K, briarane diterpenes from Junceella fragilis. J. Nat. Prod. 2008, 71, 1551-1556.

21. Chang, Y.-C.; Huang, I.-C.; Chiang, M.Y.-N.; Hwang, T.-L.; Kung, T.-H.; Lin, C.-S.; Sheu, J.-H.; Sung, P.-J. Briaviodiol A, a new cembranoid from a soft coral Briareum violacea. Chem. Pharm. Bull. 2010, 58, 1666-1668.

22. Sheu, J.H.; Sung, P.J.; Su, J.H.; Liu, H.Y.; Duh, C.Y.; Chiang, M.Y. Briaexcavatolides A-J, new diterpenes from the gorgonian Briareum excavatum. Tetrahedron 1999, 55, 14555-14564.

23. Kwak, J.H.; Schmitz, F.J.; Williams, G.C. Milolides, new briarane diterpenoids from the western pacific octocoral Briareum stechei. J. Nat. Prod. 2001, 64, 754-760. 
24. Kobayashi, J.; Cheng, J.F.; Nakamura, H.; Ohizumi, Y.; Tomotake, Y.; Matsuzaki, T.; Grace, K.J.S.; Jacobs, R.S.; Kato, Y.; Brinen, L.S.; et al. Structure and stereochemistry of brianolide, a new antiinflammatory diterpenoid from the Okinawan gorgonian Briareum sp. Cell. Mol. Life Sci. 1991, 47, 501-502.

25. Groweiss, A.; Look, S.A.; Fenical, W. Solenolides, new antiinflammatory and antiviral diterpenoids from a marine octocoral of the genus Solenopodium. J. Org. Chem. 1988, 53, 2401-2406.

26. Sheu, J.H.; Sung, P.J.; Cheng, M.C.; Liu, H.Y.; Fang, L.S.; Duh, C.Y.; Chiang, M.Y. Novel cytotoxic diterpenes, excavatolides A-E, isolated from the Formosan gorgonian Briareum excavatum. J. Nat. Prod. 1998, 61, 602-608.

27. Sheu, J.H.; Sung, P.J.; Huang, L.H.; Lee, S.F.; Wu, T.; Chang, B.Y.; Duh, C.Y.; Fang, L.S.; Soong, K.; Lee, T.J. New cytotoxic briarane diterpene from the formosan gorgonian Briareum sp. J. Nat. Prod. 1996, 59, 935-938.

28. Sklar, L.A.; McNeil, V.M.; Jesaitis, A.J.; Painter, R.G.; Cochrane, C.G. A continuous, spectroscopic analysis of the kinetics of elastase secretion by neutrophils. The dependence of secretion upon receptor occupancy. J. Biol. Chem. 1982, 257, 5471-5475.

29. Hwang, T.L.; Leu, Y.L.; Kao, S.H.; Tang, M.C.; Chang, H.L. Viscolin, a new chalcone from Viscum coloratum, inhibits human neutrophil superoxide anion and elastase release via a cAMP-dependent pathway. Free Radic. Biol. Med. 2006, 41, 1433-1441.

(C) 2014 by the authors; licensee MDPI, Basel, Switzerland. This article is an open access article distributed under the terms and conditions of the Creative Commons Attribution license (http://creativecommons.org/licenses/by/3.0/). 